\title{
ERNEST ORLANDO LAWRENCE
} BERKELEY NATIONAL LABORATORY

\section{Community Wind Power Ownership Schemes in Europe and their Relevance to the United States}

\author{
Mark Bolinger
}

Lawrence Berkeley National Laboratory

1 Cyclotron Rd., MS 90-4000

Berkeley, California 94720

Environmental Energy

Technologies Division

May 2001

Download from: http://eetd.lbl.gov/EA/EMP/

The work described in this study was funded by the Assistant Secretary of Energy Efficiency and Renewable Energy of the U.S. Department of Energy under Contract No. DE-ACO3-76SF00098. 


\section{Disclaimer}

This document was prepared as an account of work sponsored by the United States Government. While this document is believed to contain correct information, neither the United States Government nor any agency thereof, nor The Regents of the University of California, nor any of their employees, makes any warranty, express or implied, or assumes any legal responsibility for the accuracy, completeness, or usefulness of any information, apparatus, product, or process disclosed, or represents that its use would not infringe privately owned rights. Reference herein to any specific commercial product, process, or service by its trade name, trademark, manufacturer, or otherwise, does not necessarily constitute or imply its endorsement, recommendation, or favoring by the United States Government or any agency thereof, or The Regents of the University of California. The views and opinions of authors expressed herein do not necessarily state or reflect those of the United States Government or any agency thereof, or The Regents of the University of California.

\section{Acknowledgements}

This report was funded by the Assistant Secretary of Energy Efficiency and Renewable Energy of the U.S. Department of Energy under Contract No. DE-ACO3-76SF00098. The support of Jack Cadogan of the United States Department of Energy is particularly acknowledged. The author would like to thank Ryan Wiser and Chuck Goldman of Lawrence Berkeley National Laboratory, and Richard Norgaard of the University of California at Berkeley, for providing review comments on earlier drafts of this report. 


\section{TABLE OF CONTENTS}

1. INTRODUCTION .........................................................................................1

2. The Relative Merits Of COMMUNity Wind OWNERSHIP .........2

2.1 Commercial Financing - The United States .............................................2

2.2 Community Financing - Europe...............................................................................3

2.3 Defining “Community” .............................................................................................3

2.4 A Comparison of Commercial and Community Wind Development ......4

2.4.1 Advantages of Community Ownership........................................................................ 4

2.4.1.1 New Source of Capital ............................................................................................... 4

2.4.1.2 Lower Cost of Capital ................................................................................................. 4

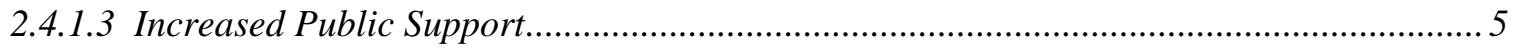

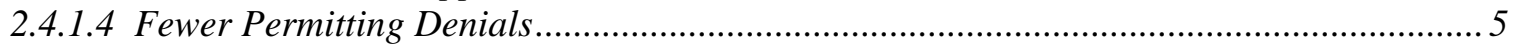

2.4.1.5 Potential for Distributed Generation Benefits.................................................................. 5

2.4.1.6 Electricity Price Stability …………………………………………………………….

2.4.2 Disadvantages of Community Ownership .................................................................. 6

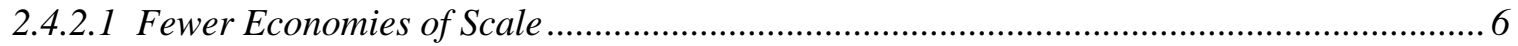

2.4.2.2 Greater Administrative Burden.......................................................................................

2.5 Summary ...............................................................................................................7

3. EUROPEAN CASE STUDIES ..........................................................9

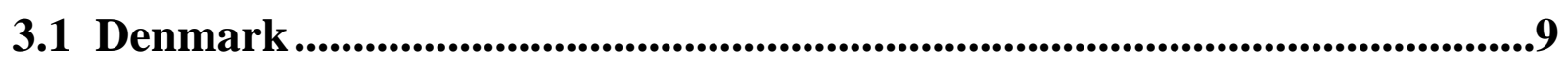

3.1.1 Background and Wind Development Trends.......................................................... 9

3.1.2 Support for Wind Power .......................................................................................... 11

3.1.3 Community Ownership Models................................................................................. 12

3.1.3.1 Wind Partnerships ("Interessentskab" or "I/S") ........................................................... 12

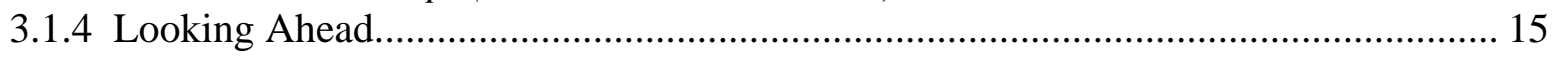

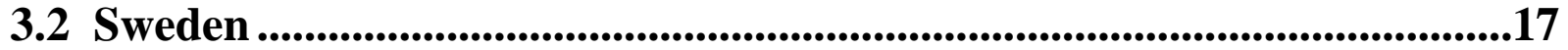

3.2.1 Background and Wind Development Trends............................................................ 17

3.2.2 Support for Wind Power ................................................................................................ 18

3.2.3 Community Ownership Models............................................................................... 19

3.2.3.1 Vindsamfällighet (real estate commune).................................................................... 20

3.2.3.2 Vindkonsumföreningar (consumer cooperative selling to the utility)............................... 22

3.2.3.3 Vindkonsumföreningar (consumer cooperative selling directly to members) ................... 25

3.2.4 Looking Ahead............................................................................................................. 27

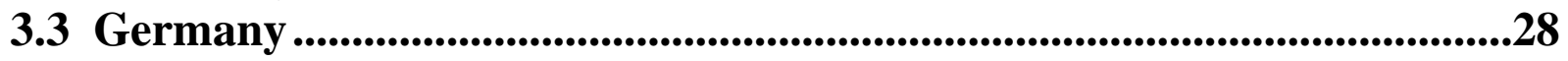

3.3.1 Background and Wind Development Trends........................................................... 28

3.3.2 Support for Wind Power ……………………..................................................... 29

3.3.3 Community Ownership Models....................................................................................... 31

3.3.3.1 GmbH \& Co. KG (limited partnership with a limited liability company as general

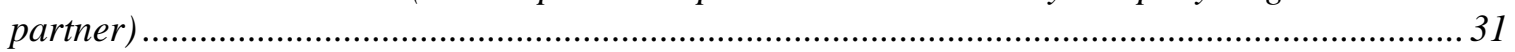

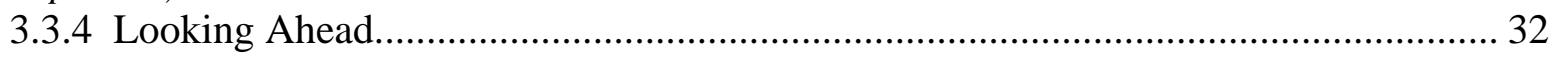

3.4 The United Kingdom.................................................................................................33

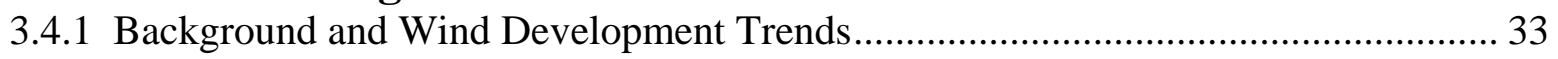

3.4.2 Support for Wind Power ........................................................................................ 33 
3.4.3 Community Ownership Models............................................................................... 35

3.4.3.1 Industrial and Provident Society (IPS) …………………................................................ 36

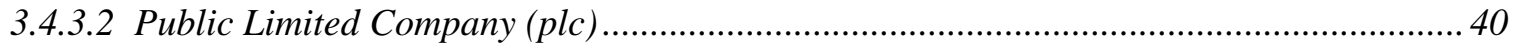

3.4.4 Looking Ahead.................................................................................................... 41

4. SUMMARY OF EUROPEAN EXPERIENCE ...................................43

4.1 Categorization of European Models.........................................................43

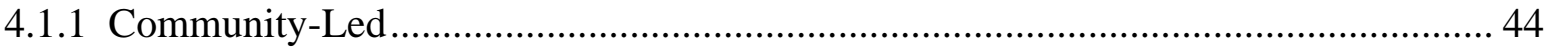

4.1.2 Developer-Led ................................................................................................. 45

4.1.3 Investment Funds ...................................................................................................... 46

4.2 Aggregate Impact of Community Wind Power Ownership in Europe..46

4.3 Factors Enabling Community Ownership .......................................................47

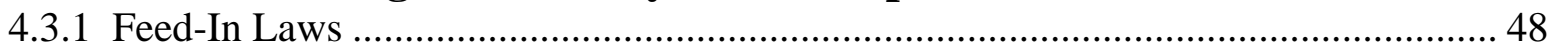

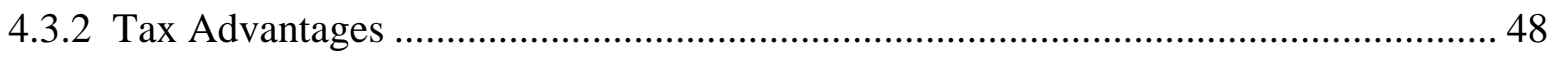

4.3.3 Standard Interconnection Agreements....................................................................... 49

4.3.4 Wind Turbine Manufacturing Base ............................................................................. 49

4.3.5 Familiarity with Cooperative Ownership Structures .................................................. 49

4.4 Inherent Benefits of Community Ownership ..................................................50

5. APPLICABILITY TO THE UNITED STATES .....................................52

5.1 Barriers to Community Wind Ownership in the United States...............52

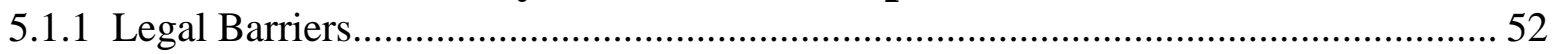

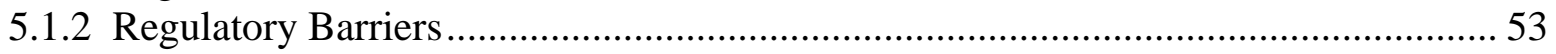

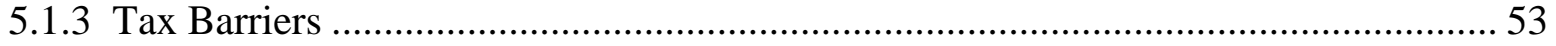

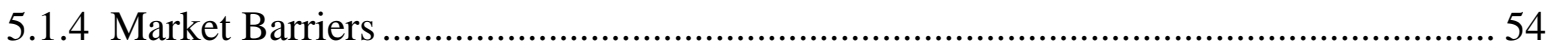

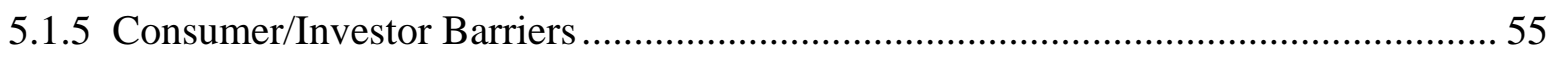

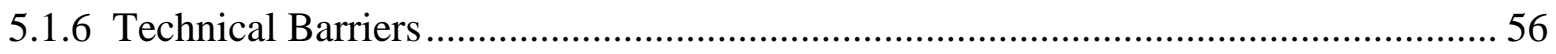

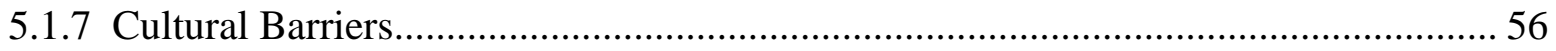

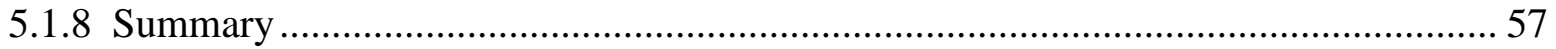

5.2 Potential Applications ........................................................................58

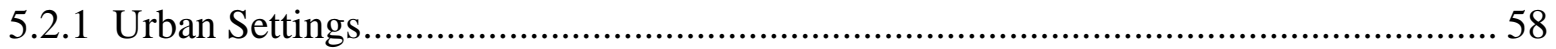

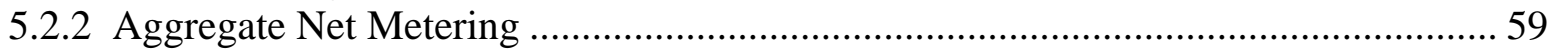

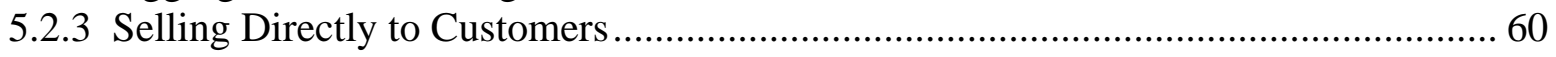

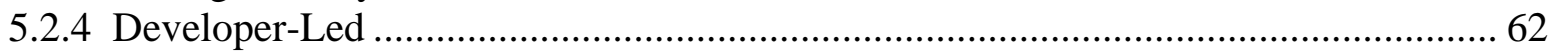

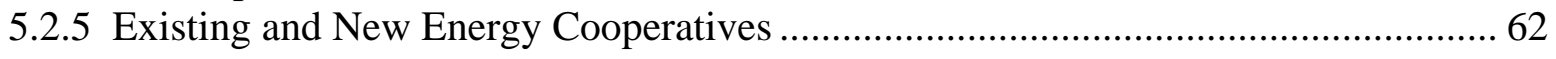

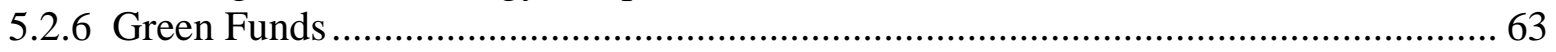

6. CONCLUSION AND NEXT STEPS ..................................................64

BIBLIOGRAPHY ...............................................................................65 


\section{INTRODUCTION}

With varying success, the United States and Europe have followed a more or less parallel path of policies to support wind development over the past twenty years. Feed-in laws and tax incentives first popularized in California in the early 1980s and greatly expanded upon in Europe during the 1990s are gradually giving way to market-based support mechanisms such as renewable portfolio standards, which are being implemented in one form or another in ten US states and at least three European nations. At the same time, electricity markets are being liberalized in both the US and Europe, and many electricity consumers are being given the choice to support the development of renewable energy through higher tariffs, both in traditionally regulated and newly competitive markets.

One notable area in which wind development in Europe and United States has not evolved in common, however, is with respect to the level of community ownership of wind turbines or clusters. While community ownership of wind projects is unheard of in the United States, in Europe, local wind cooperatives or other participatory business schemes have been responsible for a large share of total wind development. In Denmark, for example, approximately 80\% of all wind turbines are either individually or cooperatively owned, and a similar pattern holds in Germany, the world leader in installed wind capacity. Sweden also has a strong wind cooperative base, and the UK has recently made forays into community wind ownership.

Why is it that wind development has evolved this way in Europe, but not in the United States? What incremental effect have community-owned wind schemes had on European wind development? Have community-owned wind schemes driven development in Europe, or are they merely a vehicle through which the fundamental driving institutions have been channeled? Is there value to having community wind ownership in the US? Is there reason to believe that such schemes would succeed in the US? If so, which model seems most appropriate, and what barriers - legal, regulatory, tax, market, or investment - stand in the way of implementing such a scheme? These are the questions this report seeks to address.

The report begins with a discussion of the relative advantages and disadvantages of community wind ownership, as opposed to the large commercially-owned projects that have so far dominated US wind development. Next, four detailed case studies relate community-owned wind experience in Denmark, Sweden, the UK, Germany, focusing primarily on the different participatory models employed in each country. The report then categorizes the various models into three main groupings - community-led, developer-led, and investment funds - and draws general conclusions about the success of each category in Europe, and the conditions that dictate the effective use of one approach over another. Finally, the focus shifts to the US, where the report discusses the domestic barriers facing each model category, and identifies the category offering the most value with the fewest barriers to implementation. The report concludes with a high-level introduction to potential applications for community wind ownership within the United States. 


\section{The Relative Merits OF COMMUNITY Wind OWNERSHIP}

Before discussing the relative advantages and disadvantages of community wind ownership, it is necessary to define what is generally meant by "community wind ownership" and, moreover, "community", as well as the alternative form of ownership and finance to which it is being compared - commercial wind ownership. This chapter begins with an overview of commercial wind farm financing in the United States and community-financing in Europe. Next, it explores the idea of "community" more thoroughly, describing the two types of community relevant to community-owned wind projects. Finally, it describes the relative advantages and disadvantages of community ownership relative to commercial ownership, and concludes by summarizing the conditions that favor one approach over another.

\subsection{Commercial Financing - The United States}

Wind development in the United States has been overwhelmingly commercial in nature, and has typically been financed in one of two ways: project finance (also known as "non-recourse" or "off balance sheet” finance), or corporate finance (also known as "balance sheet” finance). Under project finance, up to $80 \%$ of a wind project is financed by debt borrowed against the future revenue stream of the project, as guaranteed by a long-term power purchase agreement whose length exceeds the maturity of the debt. Project finance is typically used when the developer or owner lacks sufficient assets or credit against which to borrow the necessary amount of capital; this could occur if the developer or owner chooses to insulate his other assets (i.e., the rest of his balance sheet) from creditors by forming a new company whose sole purpose is to develop the project. Since the newly formed sole-purpose development company has few assets and no credit history, the revenue stream from the project itself is the only collateral available to the lender. Project finance is therefore quite risky to the lender, who typically requires a team of lawyers, accountants, and engineers to perform rigorous due diligence before entering into a deal, and even then charges a premium over market rates, making project finance an expensive form or wind development (yet one favored by most developers because it shifts much of their risk to creditors).

Corporate or balance sheet finance is a more traditional and familiar form, in which a company essentially adds the project to its balance sheet, effectively borrowing against all its assets (i.e., its entire balance sheet) to obtain the funds necessary to develop the project. Since a company's current assets are usually much more creditworthy than is the future revenue stream of the project, companies using corporate finance can typically secure a lower cost of capital than under project finance, which reduces the cost of the wind power and increases the profitability of the project. Typically only the largest developers or wind turbine owners employ corporate finance. 


\subsection{Community Financing - Europe}

While almost all wind projects in the United States have been either project or corporate financed, up until recently these two methods were seldom seen in Europe. Instead, Europe has traditionally relied on a system of community ownership and financing of wind projects, in which individual citizens, or groups of citizens, invest the necessary equity to purchase and install one or more turbines, and then sell the electricity to the local utility at a profit. Because the amount of capital that can be raised in this manner is typically modest, and many of these projects have been intended to offset personal electricity consumption, project size has typically been small, usually only a few MW. As a result, parts of the European landscape, and much of Denmark's in particular, are dotted with small wind clusters, as opposed to the United States, where wind farms tend to be quite large and concentrated in only a few areas.

There are several different community ownership models, differing mainly along political boundaries. Denmark, where community ownership began, makes use solely of general partnerships that for the most part operate according to cooperative principles. Sweden has employed two models - the real estate commune and the consumer cooperative. Germany's primary model is more commercial in nature - a limited partnership with a developer's limited liability company as general partner. The UK, which lacks cooperative laws, has employed a legal structure known as an industrial and provident society, which operates like a cooperative, though is not bound by strict cooperative limits on investment. The UK has also pursued an investment fund structure, which is similar in nature to a mutual fund, though it invests in renewable energy projects and not publicly traded companies. Each of these models is explored in depth in the European case studies section of this paper.

\subsection{Defining “Community”}

The UK literature distinguishes between two types of communities relevant to wind ownership "communities of locality" and "communities of interest" (R. Mitchell 1994). Communities of locality are made up of people living in a certain geographical area, be it a small village, a county, or a densely populated city. Communities of interest are comprised of individuals living in many different communities of locality that nevertheless share a common interest (e.g., to promote the development of wind power).

Either type of community can own a wind project. Residents of a village (i.e., a community of locality) in a windy area may decide to take advantage of their resource and band together to purchase and install one or more wind turbines. Likewise, environmentally conscious investors located throughout an entire nation (i.e., a community of interest) may pool their money in a centralized "wind fund" used to finance new wind projects throughout the country. There is often considerable overlap and interaction between these two types of communities: the community of interest (i.e., investors in the wind fund) may identify a promising site, and then invite the community of locality (i.e., local residents, some of whom may also be investors in the wind fund) to share in the ownership of the project. 
In fact, whether or not it joins in the ownership of the project, the community of locality is almost always involved in a project at least indirectly, in the sense that it controls the local planning process, and therefore the right to prevent a project from being built. For this reason, communities of interest - as well as commercial developers - have found it useful to involve the community of locality in a project as early as possible, and one way to accomplish this is by offering ownership shares in the project.

\subsection{A Comparison of Commercial and Community Wind Development}

While the various ownership models developed to accommodate one or both types of communities have their pros and cons, the purpose of this section is not to compare different community ownership models to one another - that comparison will be made later in the paper. Instead, the intent of this section is to compare community wind ownership in its broadest sense to commercial wind ownership.

\subsubsection{Advantages of Community Ownership}

\subsubsection{New Source of Capital}

Community ownership enables wind developers to tap into a previously untapped, and often badly needed, source of investment capital - the private investor. The unprecedented amount of money flowing from private investors into stock markets around the world during the 1990s attests to the potential impact such investors could have on wind development.

\subsubsection{Lower Cost of Capital}

While in economic theory the opportunity cost of capital for all investors is the market rate of return, in practice the opportunity cost of capital for a private individual is often the rate of return on a money market fund or treasury bond - significantly lower than the double-digit returns demanded by commercial financiers. Furthermore, the increasingly popular practice of socially responsible or ethical investing - which has grown to more than \$2 trillion in the United States alone - indicates that many individuals are willing to accept a below-market return in order to support a cause in which they believe. ${ }^{1}$ Thus, wind developers with access to small investor capital can often secure financing at rates well below those expected by commercial financiers. Lower financing costs can have a significant impact on the levelized cost of energy: Wiser and Pickle (1997) estimate that reducing the required return on equity from $18 \%$ to $12 \%$ can lower the cost of wind power by $22 \%$.

\footnotetext{
${ }^{1}$ Whether or not investments that are made according to social criteria perform worse than the overall market has yet to be proven. Some argue that a socially responsible company should outperform the general market, as it is less likely to face penalties or stringent regulation, and may have more dedicated employees.
} 


\subsubsection{Increased Public Support}

Direct community ownership of wind projects raises public awareness and increases the number of individuals with a stake in the success of wind energy. This, in turn, may raise the level of public support for wind energy, and for policies that support wind energy. Commercial projects, on the other hand, sometimes encounter resistance from local communities, which view them as "big business" invading their landscape. As clearly demonstrated in the United Kingdom, such conflicts can erode public support for wind energy (NATTA 1999).

\subsubsection{Fewer Permitting Denials}

Because they benefit the community financially, increase public support for wind power, and tend to be smaller in size, community-owned wind projects are less likely than commercial projects to encounter public opposition at the planning and permitting stages. This has become particularly important in the UK, where intense planning opposition has been a perennial thorn in the side of wind developers. While perhaps more rare than in the UK, community resistance to large commercial wind projects is not unheard of in the US (O’Bryant 2001b).

\subsubsection{Potential for Distributed Generation Benefits}

The typical small size of community-owned projects, combined with local community pride, creates the potential to site projects close to load, thereby possibly reducing transmission costs and/or the need for new transmission lines or upgrades. In Europe, wind clusters are often interconnected directly to a robust three-phase distribution grid without requiring any grid reinforcement. While a weak single-phase distribution grid throughout much of the rural US will limit the degree to which Europe’s experience can be replicated domestically (Princeton Economic Research Inc. 1998), distributed generation benefits may still be realized in more developed areas of the US.

In fact, while many may think of rural agricultural areas whenever they hear about wind cooperatives, several recent projects have targeted more densely populated urban areas. Copenhagen has two community-owned wind projects totaling 7.8 MW sited within its city limits, and a third $40 \mathrm{MW}$ project (half community-owned) just off of its harbor in the narrow strait between Denmark and Sweden. Toronto is also in the midst of developing a cooperatively owned wind turbine along its lakefront. Such areas may be particularly attractive for wind development given their large loads, typical urban air quality problems, industrial landscapes, and in some areas, transmission constraints.

Large commercial wind projects, on the other hand, must often be sited far away from loads, providing no distributed generation benefits and even requiring the construction of new transmission lines.

\subsubsection{Electricity Price Stability}

Depending on how the project is structured, it may be possible for investors in a communityowned wind project to lock in the price they will pay for electricity in the future. As 
demonstrated by the sharp rise in electricity prices in the western United States starting in the summer of 2000, such a price hedge can be quite valuable.

\subsubsection{Disadvantages of Community Ownership}

The disadvantages of community ownership are fewer in number than the relative advantages, but perhaps just as large or larger in impact.

\subsubsection{Fewer Economies of Scale}

While the dichotomy of large versus small projects does not necessarily map directly to commercially- versus community-owned projects, ${ }^{2}$ a fairly strong correlation does exist, for good reason. Communities generally do not become involved with wind turbine ownership as a means of making a living (otherwise they would become a commercial developer or independent power producer), but rather to supply the community's electricity needs in a sustainable manner, while perhaps earning some investment income at the same time. This is particularly true for communities of locality. Communities of interest, on the other hand, may have a broader interest - financial or environmental - in seeing wind power more widely developed, and may also be able to raise significantly more investment capital from a wider geographic investor base than is available to a community of locality. Projects initiated by a community of interest will therefore generally tend to be larger than those initiated by a community of locality. Even these larger projects, however, may be smaller on average than a standard commercial development. Thus, to a first approximation, it is reasonable to associate community ownership with small projects and commercial ownership with large projects.

Large projects are able to spread the many fixed costs of wind development - negotiating the permitting process, legal fees, hiring a crane to erect the turbines, and building roads to access the site, transmission lines to deliver the power, and a substation to interconnect to the grid over many turbines, and may even receive volume discounts from turbine manufacturers, thereby achieving economies of scale not available to smaller projects.

On the other hand, smaller projects may not incur some of the fixed costs listed above: small projects may be sited in more populous areas where road access already exists and new transmission lines (and even grid reinforcement) are not necessary, and small projects that are community-financed may not experience the high legal fees associated with typical project finance. Furthermore, once operating, small projects may experience fewer shadow effects or array losses than larger projects.

While there will likely be situations where economies of scale are difficult to achieve, and perhaps even situations where diseconomies of scale outright favor community ownership, on balance, small community projects will be disadvantaged relative to commercial projects by their inability to achieve economies of scale. For example, in the last three rounds of the UK's NonFossil Fuel Obligation (NFFO), the average bid price of small wind projects exceeded the

\footnotetext{
${ }^{2}$ The world's largest offshore wind farm to date - a 40 MW project sited at the Middelgrunden sand bank just off of Copenhagen's harbor - is half-owned by a Danish “cooperative”, with most members living in the Copenhagen area. At the same time, commercial development of projects of $5 \mathrm{MW}$ or less is not unheard of.
} 
average bid price of large projects by $22 \%, 29 \%$, and $45 \%$, respectively (see the UK case study and Text Box 3 for a discussion of the NFFO, and Table 5 for specific bid prices).

\subsubsection{Greater Administrative Burden}

While the litigious world of project finance in which commercial wind projects typically dwell is no paradise (Probyn 2000), at least the number of parties with which the developer must interact is usually limited to a handful. Community-owned projects, on the other hand, can become quite cumbersome, depending on just how involved the community becomes, as well as how many investors there are. If, however, the community ownership structure is set up with a strong central governing board that encourages passive (rather than active) investment, a developer's dealings with the community should not be too different from what would be expected under a more traditional commercial ownership structure. ${ }^{3}$ In fact, in many cases it is well worth the developer's time and bother to ensure the community's wholehearted endorsement at a crucial planning milestone, and one way to encourage such support is to offer the community a financial stake in the project's success.

\subsection{Summary}

Since it is difficult to place a monetary value on many of these advantages and disadvantages, it is hard to say definitively that community-owned wind development is superior to commercial development, or vice versa. There are compelling arguments to be made for both methods under appropriate conditions, and it may be that the final judgment can only be rendered on a projectspecific basis. In general, however, community ownership of wind projects may be favorable under the following conditions:

- Economies of scale cannot be achieved, perhaps due to a scarcity of suitable land on which to site larger wind farms.

- The potential to realize distributed generation benefits is large.

- Financing from traditional commercial sources is either unattractive or, for small projects, perhaps non-existent.

- Community support is necessary to usher the project through the planning and permitting stages.

Commercial ownership of wind projects will generally be favorable under the opposite set of conditions:

- Economies of scale can be realized by larger wind farms, as suitable sites are readily available, environmental impacts are minimal, and competing uses are few in number.

- The potential to realize distributed generation benefits is low, and transmission access to load centers is adequate, or can be built at an acceptable cost.

\footnotetext{
${ }^{3}$ Setting a minimum investment threshold can also lessen administrative burden by reducing the number of shareholders. In general, however, the marginal administrative burden of each additional investor will be quite small relative to the initial fixed costs of setting up the community-ownership structure.
} 
- Financing from traditional commercial sources is fairly priced and readily available.

- No planning or permitting difficulties are anticipated.

The first set of conditions, and in particular the first two bullets dealing with economies of scale and distributed generation benefits, are perhaps more characteristic of Europe, while the second set of conditions (again, particularly the first two bullets) more closely describe the United States. In this sense, the focus to date on commercial development and ownership in the United States and community ownership in Europe appears to be appropriate.

At the same time, however, there are also a multitude of areas in the United States that adhere to the conditions favoring community over commercial wind ownership. Given the existence of both types of environments in the US, and the benefits of pursuing community ownership where warranted, it is remarkable that there are no community-owned wind projects in the United States. This is particularly notable in light of the success they've garnered in Europe, as described in the next chapter. 


\section{EUROPEAN CASE STUdies}

This chapter explores in depth community ownership of wind projects in Denmark, Sweden, Germany, and the UK. Each of the four case studies begins with an overview of wind development in that country, followed by an overview of policies supporting wind development. Next, the specific community ownership model or models employed in each country are analyzed in terms of operations, taxation, financing, liability, and liquidity. Every attempt is made to keep the analysis generic and non-project-specific, though in some cases where a model has been deployed only once or twice, this becomes more difficult. Projects that exemplify a model particularly well and for which sufficient information exists are set apart in text boxes. Each case study concludes with a summary of current conditions, and a prognosis for the future.

\subsection{Denmark}

"Looking at the Danish landscape, you could easily imagine that wind mills grew by themselves from seeds, like trees and flowers. They do however need to be planted." - Peter Helby (1997)

\subsubsection{Background and Wind Development Trends}

For many years, tiny Denmark, with a land area roughly the size of New Hampshire and Vermont combined and a population of about five million, was second only to the United States in terms of installed wind capacity. Germany surpassed Denmark in 1994, as did Spain in 2000, but with almost 2300 MW currently installed, representing nearly 14\% of the world's wind capacity, Denmark still ranks fourth in the world, behind Germany, Spain, and the United States. As a percentage of total electricity consumption, however, Denmark's wind generation ranks first in the world - wind power met 14\% of Denmark's electricity demand in 2000.

As shown by Figure 1, wind development in Denmark has been overwhelmingly communitybased. The first modern wind turbines installed in Denmark during the 1970s were developed and owned by private individuals without government support. To reward this high degree of private initiative and enthusiasm, and to compensate local communities for the positive externalities that accrue largely on a national rather than local level, the government has since encouraged local private ownership of wind turbines through a variety of subsidies and ownership restrictions (Andersen 1998). As a result of these policies, over 175,000 households own $80 \%$ of all wind turbines in Denmark, either on an individual basis or through “cooperatives” (Wassink 2001). 
Figure 1. Total Wind Development in Denmark (Community and Utility Ownership)

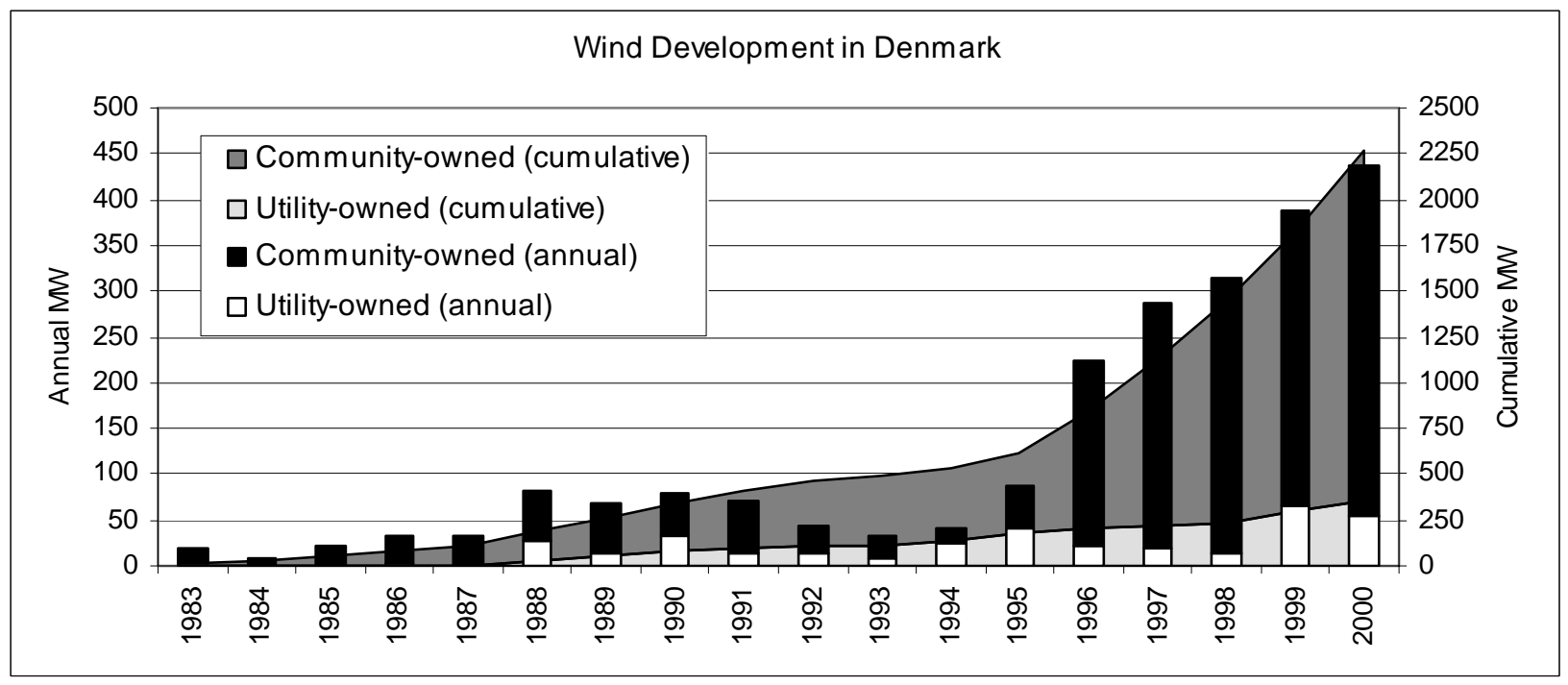

Figure 2 breaks out the community-owned portion of the previous chart into individually- and jointly-owned projects. The amount of wind capacity owned by individuals grew dramatically in the mid-1990s, fueled by a number of factors: declining turbine costs and lower interest rates, government incentives for re-powering older turbines, and a regulatory loophole allowing the small patch of land upon which a turbine stands to be legally detached from the surrounding property and re-registered to another piece of real estate, perhaps located far away, thereby enabling more individuals (i.e., those living in cities or areas with a poor wind resource) to own turbines (Andersen 1998, Helby 1998b, European Wind Energy Association 1997).

Figure 2. Community Wind Development in Denmark (Individual and Joint Ownership)

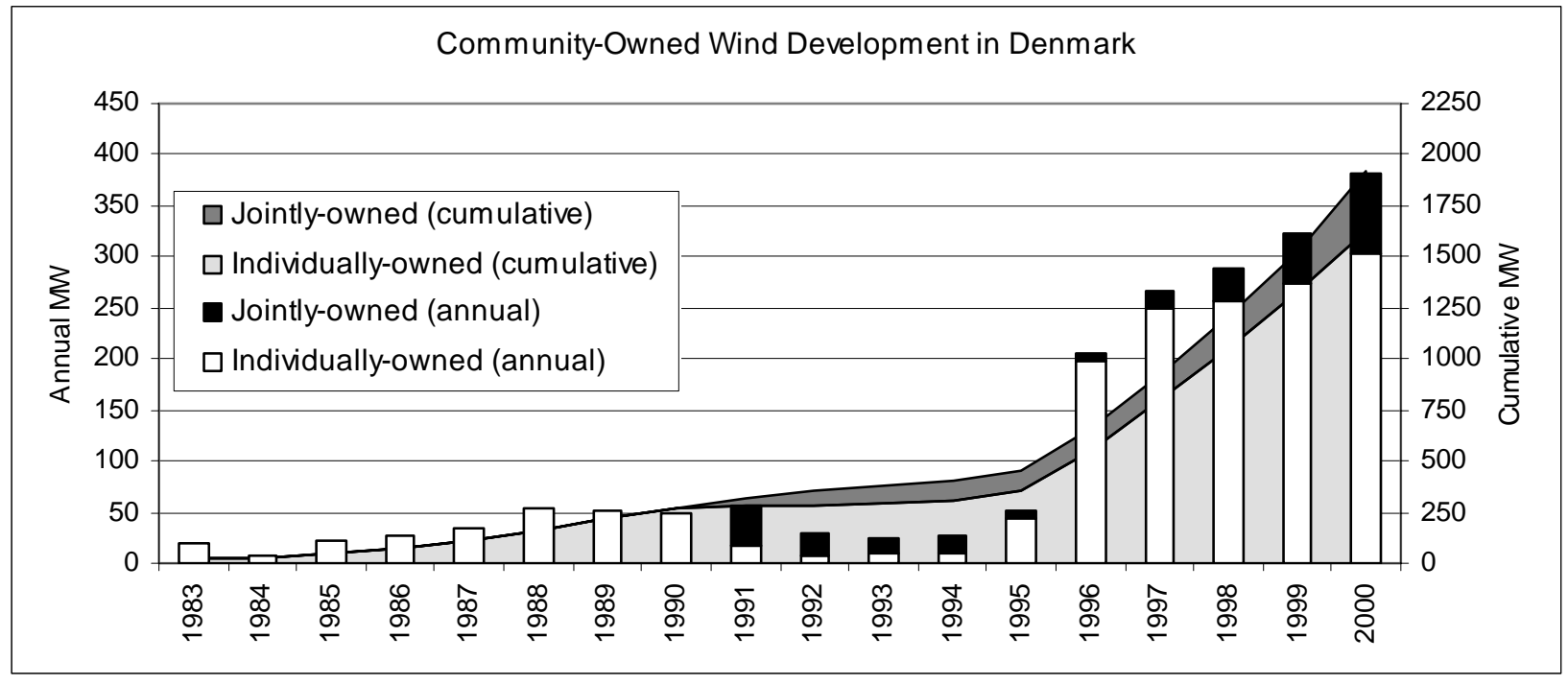




\subsubsection{Support for Wind Power}

\subsubsection{Capital Support}

In 1979 the government enacted a renewable energy program that included a capital investment subsidy of $30 \%$ of total project costs. As the industry began to mature in subsequent years, the investment subsidy was gradually phased out, and was completely withdrawn in 1989 . Over the 10 years that the subsidy was in place, a total of 2567 wind turbines received investment subsidies totaling DKK 275.72 million (in 1997 DKK) (Andersen 1998).

\subsubsection{Production Support}

Various forms of support for wind power generation have existed since 1979. This section will focus on recent forms of production-based support, as well as what can be expected in the next few years.

\section{Feed-In Laws}

Since 1993, local utilities have been required to purchase wind energy from independent generators at a rate that is $85 \%$ of their production and distribution costs. These tariffs have typically amounted to around $0.3 \mathrm{DKK} / \mathrm{kWh}$. In 1999, Denmark decided to abandon its feed-in law and move towards a renewable portfolio standard (RPS) with a system of tradable green certificates (TGC's) to support renewable energy. While the TGC market is not expected to open until 2003 (at which time all electricity consumers must purchase $20 \%$ of their electricity from qualifying renewable resources), a transitional program designed to gradually wean wind turbine owners off of their guaranteed profitable market was scheduled to begin in April 2001. Under the transitional program, the $85 \%$ feed-in tariff is replaced with a fixed-price tariff of 0.33 $\mathrm{DKK} / \mathrm{kWh}$ until a turbine is 10 years old, and at least through the end of 2002 (i.e., at least until the TGC market opens). The fixed rate of $0.33 \mathrm{DKK} / \mathrm{kWh}$ is comparable to the average price received under the $85 \%$ system, and is significantly higher than Nord Pool spot market prices today, which have lately ranged between 0.10-0.15 DKK/kWh.

\section{Environmental Subsidies}

Denmark has historically refunded the entire $\mathrm{CO}_{2}$ tax on electricity consumption $(0.10$ $\mathrm{DKK} / \mathrm{kWh}$ ) and a portion of the energy tax (amounting to $0.17 \mathrm{DKK} / \mathrm{kWh}$ ) to independent wind generators, resulting in a total subsidy of $0.27 \mathrm{DKK} / \mathrm{kWh} .{ }^{4}$ Under the transition to TGCs, turbines purchased and permitted prior to 2000 will be eligible for the full $0.27 \mathrm{DKK} / \mathrm{kWh}$ subsidy up to a certain production limit (see Table 1), and once that limit is reached, the subsidy will drop to $0.10 \mathrm{DKK} / \mathrm{kWh}$ until the turbine is 10 years old and the TGC market is open, at which point the subsidy will take the form of TGCs, whose value is determined by the market, subject to a minimum price of $0.10 \mathrm{DKK} / \mathrm{kWh}$ and a maximum price of $0.27 \mathrm{DKK} / \mathrm{kWh}$. New wind turbines purchased between 2000 and 2002 earn the fixed feed-in tariff of $0.33 \mathrm{DKK} / \mathrm{kWh}$ for the first 10 years of operation, and receive no subsidies other than TGCs (Odgard 2000). Table 1 lays out the plan to transition wind turbine owners from fixed feed-in tariffs to marketbased TGCs.

\footnotetext{
${ }^{4}$ Utility-owned wind turbines receive the $\mathrm{CO}_{2}$-tax refund, but not the partial refund of the energy tax.
} 
Table 1. Wind Power Transition Plan from Feed-In Tariffs to Tradable Green Certificates

\begin{tabular}{|c|c|c|c|c|}
\hline $\begin{array}{l}\text { Turbine } \\
\text { Vintage }\end{array}$ & $\begin{array}{c}\text { Size } \\
(\mathrm{kW})\end{array}$ & $\begin{array}{c}\text { Fixed Price } \\
(0.33 \mathrm{DKK} / \mathrm{kWh}) \\
\end{array}$ & $\begin{array}{c}\text { Fixed Subsidy } \\
(0.27 \mathrm{DKK} / \mathrm{kWh})\end{array}$ & $\begin{array}{c}\text { TGC } \\
(0.10-0.27 \mathrm{DKK} / \mathrm{kWh})\end{array}$ \\
\hline \multirow{3}{*}{ Existing* } & $<=200$ & \multirow{3}{*}{$\begin{array}{l}\text { Until the turbine is } \\
10 \text { years old (but } \\
\text { at least until 2002) }\end{array}$} & $\begin{array}{l}\text { For first 25,000 } \\
\text { full-load hours }\end{array}$ & \multirow{3}{*}{$\begin{array}{l}\text {-After full-load hour } \\
\text { limit: } 0.10 \text { DKK/kWh } \\
\text {-Once TGC market } \\
\text { opens and turbine is } 10 \\
\text { years old, turbine gets } \\
\text { TGCs instead }\end{array}$} \\
\hline & $201-599$ & & $\begin{array}{l}\text { For first 15,000 } \\
\text { full-load hours }\end{array}$ & \\
\hline & $>=600$ & & $\begin{array}{l}\text { For first } 12,000 \\
\text { full-load hours }\end{array}$ & \\
\hline $\mathrm{New}^{* *}$ & & For 10 years & NONE & YES \\
\hline
\end{tabular}

* Purchased and permitted prior to 2000

** Purchased and permitted in 2000, 2001, and 2002

\subsubsection{Interconnection}

Wind turbine owners and distribution utilities share the cost of interconnection to the grid. Independent generators must pay the cost of connecting to the nearest technically suitable point on the grid. These costs include the line from the plant to the grid connection point, control and metering equipment necessary at the grid connection point, and labor. In the event that grid reinforcement is necessary in order to interconnect the generator, or the utility requires interconnection at some more distant point, the utility must pay these extra costs. This costsharing arrangement is important in that it more or less guarantees that wind generators will be able to interconnect to the grid, and at a limited and manageable cost that is roughly known in advance.

\subsubsection{Community Ownership Models}

Only one form of community wind ownership is widely used in Denmark - the wind partnership.

\subsubsection{Wind Partnerships ("Interessentskab" or "I/S")}

\section{Background}

The famous Danish wind cooperatives are technically not cooperatives at all, but general partnerships (I/S). While cooperatives are used extensively in Denmark for other endeavors (and are even used extensively in the energy sector with combined heat and power), Danish electricity law requires that wind turbines be directly owned by electricity consumers (Helby 1998a, 1998c). A partnership, which is understood to be a contractual relationship between several entities (i.e., electricity consumers) to pool certain resources in order to run a business, is the only joint form of ownership to qualify under Danish power law.

Wind partnerships were initially developed from the bottom up by local enthusiasts trying to use existing power and tax law to their best advantage (Helby 1995). Over the years, the Danish Wind Turbine Owners association has become a powerful lobbying force, and has been able to effect changes that are more accommodating to this typical ownership structure. 


\section{Operations}

Mechanically, Danish wind partnerships are quite simple. Individuals pool their savings to invest in a wind turbine, and sell the power to the local utility at an attractive rate, historically equal to $85 \%$ of that utility's production and distribution costs, but fixed at $0.33 \mathrm{DKK} / \mathrm{kWh}$ under the transitional scheme detailed above. In addition, the wind partnership receives a full refund of the $\mathrm{CO}_{2}$ tax $(0.10 \mathrm{DKK} / \mathrm{kWh})$ and a partial refund of the energy tax $(0.17 \mathrm{DKK} / \mathrm{kWh})$. See Table 1 for the transitional subsidy plan. Investors in a wind partnership continue to pay their own electricity bills as normal - the turbine's output is sold wholesale to the utility, rather than to the individual members of the partnership.

Wind partnerships have historically been required to operate on a local basis. Since the negative external costs of wind power - namely noise and visual intrusion on the natural landscape - are borne locally, while the positive external benefits accrue on a national or global basis, the government has taken steps to ensure that only those bearing the costs receive the financial benefits of government subsidies. This strategy has gone a long way towards bolstering public support for wind power in Denmark, and has led to many small clusters of wind turbines dotting the Danish landscape.

However, as the industry matures, turbine sizes increase, and Denmark looks to a future even more reliant on wind power, the government has gradually relaxed most ownership restrictions. Thus, while in the early 1980s investment in a wind partnership was limited to those living within $3 \mathrm{~km}$ of the turbine, geographic eligibility was gradually expanded to include those living within $10 \mathrm{~km}$ (1985), those living in neighboring boroughs (1992), those who work or own property in a borough but don't live there (1996), all of Denmark (1999), and finally in 2000, the entire European Union (DWTMA at www.windpower.dk).

In exchange for relaxed geographic ownership constraints, the government has imposed stricter siting guidelines that will concentrate future development in the most appropriate windy areas. In conjunction with these new siting restrictions, the government has offered - with limited success to date - incentives to encourage owners of older and smaller turbines to replace them with new turbines of higher capacity located at the potentially windier sanctioned sites.

\section{Financing}

Shares are commonly $1000 \mathrm{kWh} /$ year, and cost about $\$ 450$ per share (assuming $\$ 1000 / \mathrm{kW}$ project costs and 25\% capacity factor). As noted under "Taxation" below, the first 3000 DKK of income each year is tax-free - this equates to an optimal investment of 5 shares, or about \$2300 total investment.

While the size of investment is often within the means of personal savings, there are numerous options for those wishing to finance their investment. Mortgage banks in Denmark will provide long-term, market-rate loans for up to $70 \%$ of the value of an applicant's real estate. Presuming that the applicant is not fully mortgaged up to this threshold, mortgage banks can be a good source of capital to those who own real estate. Financing is not necessarily linked to the strength of the project, but to the financial health of the real estate to which the project is tied. 
Denmark also has a few "ethical” banks that will loan funds for wind turbines at below-market rates. ${ }^{5}$ For example, at the 3.6 MW Avedore wind farm in southern Copenhagen, investors were able to obtain share financing from the ethical bank Faellskassen at an interest rate of 4\% (when the base rate was around 10\%), provided that they had held a savings account with Faellskassen for at least six months (Mitchell and Mackerron 1994).

Although legal restrictions on ownership structure make such comparisons moot, a partnership has at least one economic advantage over a cooperative: an individual in a partnership can deduct the interest on a loan for his share of a wind turbine from income taxes, while an individual in a cooperative cannot (DWTMA at www.windpower.dk).

\section{Taxation}

A partnership is not a taxable entity; instead, taxes are levied proportionally on each individual partner, who is taxed according to his or her individual tax situation. For many years, income from wind turbines (in a household context) has been tax-exempt, as long as it did not exceed certain limits. In 1985, those limits were either 135\% of household power costs or 6 shares, whichever was greater, while in 1992, they were increased to the greater of $150 \%$ of household power costs or 9 shares (i.e., everyone can own at least 9 shares on a tax-free basis regardless of how much electricity they consume, and those with higher electricity bills can receive tax-free income up to $150 \%$ of their annual electricity costs). The power costs were calculated very liberally, including transmission and distribution charges, taxes, and even a value-added tax (VAT) of $25 \%$.

In 1996, however, the tax laws were reformed, creating three possible taxation options. First, individuals who bought shares prior to 1996 can continue to operate under the old method of taxfree production for production that is less than $150 \%$ of annual consumption as long as they own fewer than nine shares (i.e., $9000 \mathrm{kWh} /$ year). Second, any shares bought during or after 1996 are subject to a "standard" method, in which the first 3000 DKK of income is tax-exempt, while $60 \%$ of any income above this level is taxed (usually at a marginal rate of $60 \%$ ). ${ }^{6}$ At the current guaranteed feed-in tariff of $0.60 \mathrm{DKK} / \mathrm{kWh}$ (which includes the full $\mathrm{CO}_{2}$ tax and partial energy tax refund), the $3000 \mathrm{DKK}$ tax-free limit corresponds to five shares (i.e., $5000 \mathrm{kWh} / \mathrm{year}$ ) and is meant to provide similar relief as the old method of tax exemption for own consumption. Any annual income above 3000 DKK is essentially treated as a business investment - only $60 \%$ of this excess income is taxed, simulating the tax advantages of 20-year straight-line depreciation (without forcing households to go through the calculations). Finally, any individual can choose to have income from shares taxed as ordinary business investment.

Finally, as mentioned under "Financing”, interest on a loan for a wind turbine share is tax deductible.

\footnotetext{
${ }^{5}$ The term "ethical” bank is commonly used in Europe to describe banks with a social mission. Ethical banks finance a wide array of socially beneficial activities, such as community development, conversion to organic farming practices, and the development of renewable energy. In the United States, such banks are often referred to as "community development banks", reflecting their more narrow focus on community development.

${ }^{6}$ Individuals that have purchased shares prior to 1996 can also choose to use the standard method.
} 
Liability

All partners are held jointly and severally liable for any debts incurred by the partnership, which means that personal liability extends well beyond the level of an individual's investment. Danish wind partnerships have generally dispensed with this risk, however, by modifying their bylaws to prohibit the partnership from taking on debt. This prohibition means that any financing of wind shares is done at the level of the individual, not the partnership.

\section{Liquidity}

Although shares are not traded on a public exchange, cooperative board members will usually help to match those wishing to sell their shares with prospective buyers. Shares are usually traded at par, with no adjustments for depreciation (Helby 1998a, 1998c). The relaxation of geographic ownership restrictions to the entirety of Denmark in 1999 and to the rest of the European Union in 2000 should increase the liquidity of wind partnerships, though perhaps at the expense of being able to easily identify potential buyers.

\subsubsection{Looking Ahead}

Community-owned wind stands at a crossroads in Denmark. The government's recent abolishment of ownership restrictions reflects an acknowledgement that the local market has become quite saturated, and that substantial new investment will be needed to reach Denmark's ambitious goal of supplying $50 \%$ of its electricity consumption with wind power by 2030 . At the same time, however, the transition from guaranteed feed-in tariffs to a renewable portfolio standard based on TGCs has left many convinced that the era of community wind may be coming to an end (see Text Box 1). This conviction is due to both the revenue uncertainty under an RPS, and also the fact that an RPS will likely create pressure to increase project size in order to lower costs and thereby maximize TGC income. No new wind turbines were ordered in 2000; all projects installed during 2000 had been ordered and permitted prior to the end of 1999, in order to capture the $0.27 \mathrm{DKK} / \mathrm{kWh}$ fixed subsidy under the transition plan. Without this 0.27 $\mathrm{DKK} / \mathrm{kWh}$ subsidy, the expected after-tax IRR of the Middelgrunden project, for example, would drop from an estimated $8.25 \%$ to about $4.25 \%$ over 20 years - a substantial setback. It remains to be seen whether a $4.25 \%$ after-tax IRR is enough to entice community investors to continue supporting Denmark's wind industry, or whether the lower returns, along with the greater sophistication needed to negotiate the TGC market, will truly make the private wind turbine owner a dying breed. 


\section{Text Box 1: The Middelgrunden Wind Turbine Partnership}

Danish wind advocates have lamented the passing of Denmark's long-standing feed-in tariff in favor of a market-based renewable portfolio standard, and have portended that this shift could bring an abrupt end to what has to date been the most successful wind ownership model in Denmark - the wind partnership (commonly called a "cooperative"). The recently completed 40 MW Middelgrunden project, however, is boldly proving that wind partnerships are alive and well - at least for the time being. Located about $2 \mathrm{~km}$ off of Copenhagen's harbor in the narrow sound between Denmark and Sweden, Middelgrunden is both the largest communityowned wind project ever, as well as the first sited offshore. The $40 \mathrm{MW}$ project consists of twenty 2 MW Bonus wind turbines, ten of which are owned by the partnership, with the other half owned by the local municipal utility, Copenhagen Energy. With the annual output of its ten turbines guaranteed by Bonus at 40,500 MWh, the partnership consists of 40,500 shares (each share is $1,000 \mathrm{kWh} /$ year) owned by nearly 9,000 members who invested DKK 4,250 per share for between four and five shares on average, reflecting the tax-free status of the first five shares.

While Middelgrunden has taken wind partnerships to a new level in Denmark, it could be argued that the project merely represents a "last hurrah". Because receipt of planning permission and the turbine purchase order both took place in 1999, the Middelgrunden project will for six years receive the same attractive feed-in tariff that wind turbine owners in Denmark have enjoyed in the past. In years 7 through 10, income is still guaranteed, but at a lower level, and after 10 years the project must sell both its output and its "green certificates" on the open market, which is likely to lead to lower returns in years 11 through 20 . $^{*}$ Thus, through fortunate timing, Middelgrunden remains insulated from the full impact of market pricing for the first half of its projected life-span, meaning that the high degree of investor enthusiasm it has attracted may not be indicative of what lies ahead for future partnerships that are more exposed to the market. The following table shows the expected cash flows for one 1,000 kWh/year share in the Middelgrunden project. All cash flows are virtually locked in, with the exception of the feed-in tariff in years 11-20, which is highly uncertain.

\begin{tabular}{|l|c|c|c|}
\hline & Years 1-6 & Years 7-10 & Years 11-20 \\
\hline & DKK/kWh & DKK/kWh & DKK/kWh \\
\hline Feed-In Tariff & 0.33 & 0.33 & $\mathbf{0 . 3 3}$ \\
\hline Energy Tax Refund & 0.17 & 0 & 0 \\
\hline $\mathrm{CO}_{2}$ Tax Refund & 0.10 & 0 & 0 \\
\hline Tradable Green Certificate & 0 & 0.10 & 0.10 \\
\hline $\mathrm{O} \& \mathrm{M}$ & -0.07 & -0.07 & -0.07 \\
\hline Net Cash Flow & 0.53 & 0.36 & 0.36 \\
\hline
\end{tabular}

Assuming that the project can continue to sell its output for $0.33 \mathrm{DKK} / \mathrm{kWh}$ in years $11-20$, and receives the minimum guaranteed TGC price of $0.10 \mathrm{DKK} / \mathrm{kWh}$ for all of its output, the project yields a 20-year IRR of $8.25 \%$. In a worst-case scenario, where the project is simply unable to sell any of its output in years 1120 (i.e., the 0.33 goes to zero), yet still receives the minimum guaranteed TGC price, the 20 -year IRR falls to $4.44 \%$. The first $3000 \mathrm{DKK}$ of revenue (corresponding to the first 5 shares) is free from income tax, while $60 \%$ of all revenue beyond 3000 DKK is taxed, usually at a rate of $60 \%{ }^{* *}$

The completion of Middelgrunden brings the total amount of wind power capacity in Copenhagen to 47.8 MW, enough to supply about 35,000 homes with electricity, assuming a $25 \%$ capacity factor and average usage of $250 \mathrm{kWh} /$ household/month. Wind partnerships own $27.8 \mathrm{MW}$ of that total.

For more information, see $w w w . m i d d e l g r u n d e n . d k$. For a database of each turbine's daily output, see www.middelgrund.com.

${ }^{*}$ The project has a simple payback of nine years.

${ }^{* *}$ The tax exemption on $40 \%$ of revenue in excess of 3,000 DKK reflects the effect of a 20-year straight-line depreciation; writing off $5 \%$ of the investment each year reduces taxable income by about $40 \%$. 


\subsection{Sweden}

\subsubsection{Background and Wind Development Trends}

As a result of having both a relatively clean power-generation industry and an abundant supply of cheap hydropower accessible both domestically and from Norway, the development of nonhydro renewable energy in Sweden has traditionally been viewed as more of a long-term priority rather than a short-term need. As such, government support has emphasized research rather than implementation; Sweden has had some of the best-funded renewable energy research programs in the world, yet actual development and implementation of projects has been limited (Helby 1998f).

The evolution of Swedish policy towards nuclear energy, however, has provided a niche that renewables can exploit. Following a 1980 public referendum, Sweden's government decided to shut down all nuclear reactors by 2010. In 1991, this hard-line stance was moderated to allow existing reactors to serve out their useful life, even if it spans beyond 2010 (Helby 1998f). In December 1997, policy took yet another turn as the Riksdag passed the Nuclear Power Decommissioning Act, which gives the government the power to close any nuclear power plant at any time. In concert with the Act, however, is a general policy that nuclear reactors will only be closed provided that the resulting loss in capacity can be offset by a combination of reduced electricity consumption and new renewable generation. Under the Act, the $600 \mathrm{MW}$ Barsebäck 1 nuclear reactor was decommissioned on November 30, 1999, reducing Sweden's nuclear capacity by 6\% (Swedish National Energy Administration 2000). Barsebäck 2 is currently scheduled to be decommissioned in late 2001. It is this trend towards nuclear decommissioning that has been driving the development of wind energy in Sweden during the 1990s.

Figure 3 shows annual and cumulative installed wind capacity in Sweden back to 1990, by type of ownership. At the end of 2000, Sweden had about 240 MW of installed wind capacity, 25 MW of which was community-owned. Note that while total capacity numbers for 1999 and 2000 are accurate, the community ownership category for those years is estimated, and likely to be understated.

Figure 3. Wind Development in Sweden (Community and Other Ownership)

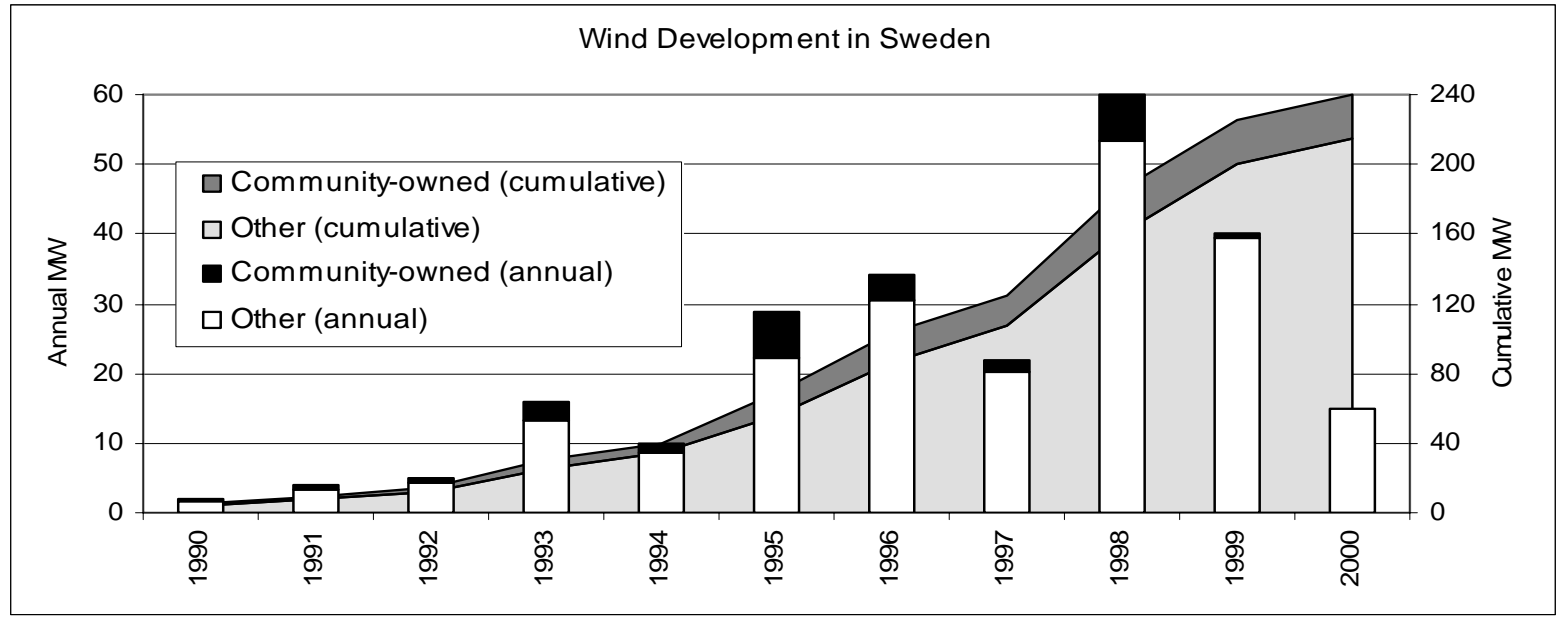

Note: Community-owned figures for 1999 and 2000 are approximate. 


\subsubsection{Support for Wind Power}

\subsubsection{Capital Support}

Government financial support for wind power development has come mainly in the form of subsidies for direct capital investment in wind turbines. This is largely a result of fiscal conservatism and political compromise: the total amount of available investment subsidies is known and immediately reflected in the current budget, and once the amount is fully allocated to projects, subsidies effectively disappear until reinstated, which requires further political negotiations and ensures that the subsidy does not become institutionalized (Helby 1998f).

Such a politically driven subsidy has subjected wind development in Sweden to boom/bust cycles. Between 1991 and 1996, wind turbines greater than $60 \mathrm{~kW}$ capacity were eligible for an investment subsidy equal to 35\% of total project costs (excluding land); SEK 350 million was made available for this purpose (Haas et al 2001). Subsidies were distributed on a first-come first-served basis, and once the total budgeted amount was distributed, no subsidies were available for much of 1996 and 1997. A refunding occurred in 1998, but at a reduced subsidy of $15 \%$ of project costs for turbines larger than $200 \mathrm{~kW}$ that have project costs of less than 4,600 SEK/MWh ( $\sim 460 / \mathrm{MWh})$. Through June 2002, 300 million SEK ( $\$ 30$ million) is available, but only one month into the program in 1998, applications for a total of 665 million SEK had been submitted, forcing the government to ration based on project quality (Helby 1998f).

\subsubsection{Production Support}

\section{Feed-In Laws}

Sweden's 1996 electricity deregulation law requires local utilities to continue to buy power at a "fair" price from independent renewable generators of less than $1.5 \mathrm{MW}$ capacity. While the price paid varies by utility, most utilities have historically upheld the spirit of this agreement, paying wind generators the average price at which the utility otherwise buys power plus compensation for the fact that the seasonal fluctuations in wind power closely match seasonal fluctuations in load, which peak during the long, cold, dark winter (Helby 1998f). The average payment for wind energy over the course of the year has historically been about SEK 0.250.29/kWh (Wizelius 2001).

Following the opening of Sweden's residential market to competition in November 1999, however, the price paid for wind power has fallen by $40 \%$ to $50 \%$, reflecting new competitive pressures facing power marketers, as well as the unusually low prices in the Nord Pool electricity market. Under the new competitive market, many wind generators initially contracted for a year at a price ranging from SEK 0.13-0.19/kWh. As these contracts expire, most wind generators now simply receive the spot price from the Nord Pool exchange. This market rate is augmented with an "environmental bonus" and a special payment from the government in compensation for low power prices (see below). 


\section{Environmental Bonus}

Electricity consumption is taxed in Sweden. The full amount of this tax, per kWh, is passed through to wind generators as an "environmental bonus". The tax stood at $0.181 \mathrm{SEK} / \mathrm{kWh}$ $(\sim 1.8 \$ / \mathrm{kWh})$ in 2001 , and is indexed to inflation.

Compensation for Low Power Prices

Sweden's 1996 electricity deregulation law promised to protect wind power from uncontrollable fluctuations in the market. As unusually low Nord Pool power prices caused the price paid to wind generators to drop by $40 \%-50 \%$ upon the opening of the residential market to competition in November 1999, the Swedish government instituted an additional production incentive of 0.09 $\mathrm{SEK} / \mathrm{kWh}$ for all wind, solar, and hydro generators under $1.5 \mathrm{MW}$ nameplate capacity. This incentive will most likely remain in effect through 2002, or until power prices return to "normal" levels.

\subsubsection{Interconnection}

As in Denmark, independent generators must pay the cost of connecting to the nearest technically suitable point on the grid. In the event that grid reinforcement is necessary in order to interconnect the generator, or that the utility requires interconnection at some more distant point, the utility must pay these extra costs. The transparency of this cost-sharing arrangement allows wind developers to more accurately forecast total project costs.

\subsubsection{Community Ownership Models}

Community wind ownership schemes have existed in Sweden since 1989, when the founders of Vindkompaniet AB started the first Vindsamfällighet (real estate commune) on the island of Gotland, where much of Sweden's installed wind capacity resides. Community ownership schemes have generally fallen into one of two models: Vindsamfälligheter (real estate communes) and Vindkonsumföreningar (consumer cooperatives). Table 2 provides relevant statistics for both models as of early 1999 (Wizelius 1999a, 1999b). Recent estimates place the number of members closer to 15,000 (Envall 2001), with more than $30 \mathrm{MW}$ installed (Wizelius and Samstag 2000).

Table 2. Community Wind Ownership in Sweden (1999)

\begin{tabular}{|c|c|c|c|c|c|}
\hline & $\begin{array}{l}\text { Number of } \\
\text { Organizations }\end{array}$ & $\begin{array}{l}\text { Installed } \\
\text { Capacity } \\
\text { (MW) }\end{array}$ & $\begin{array}{c}\text { Number of } \\
\text { Members }\end{array}$ & $\begin{array}{c}\text { Total } \\
\text { Investment } \\
\text { (SEK) }\end{array}$ & $\begin{array}{c}\text { Average } \\
\text { Investment/Member } \\
\text { (SEK) }\end{array}$ \\
\hline $\mathrm{Vi}$ & 18 & 8.2 & 2,581 & $67,600,000$ & 26,200 \\
\hline Vindkonsumföreningar & 33 & 17.1 & 6,927 & $107,700,000$ & 15,540 \\
\hline Total & $\overline{51}$ & $\overline{25.3}$ & $\overline{9,508}$ & $\overline{175,300,000}$ & $\overline{18,434}$ \\
\hline
\end{tabular}

Source: Wizelius, 1999a, 1999b

Throughout the 1990s, real estate communes and consumer cooperatives have operated primarily on a local level, selling their power to the local utility at the agreed upon feed-in tariff. More recently, however, at least one consumer cooperative has begun to sell wind power directly to its members at cost, initially on a local basis, but now, with the market fully open, also on a nationwide basis. Each of these three models - the local real estate commune selling to the 
utility, the local consumer cooperative selling to the utility, and the national consumer cooperative selling directly to its members - is described below.

\subsubsection{Vindsamfällighet (real estate commune)}

Background

While it is perhaps the most unusual ownership structure by western standards, the real estate commune is a common form of community wind ownership in rural Sweden. It is based on the traditions of common law and communal ownership of physical resources, such as fishing or grazing rights, which were often attached to land titles (e.g., one must own land along a stream or in a village in order to fish in that stream or pasture livestock in the village field). Somewhat unique to Sweden, this common law tradition has evolved into a modern vehicle for communal ownership of public facilities such as parking lots, playgrounds, and now wind turbines (Helby 1998d).

\section{Operations}

Operationally, communal ownership of a wind turbine is relatively simple. Real-estate owners band together, establish a real estate commune, and pool their funds to install one or more wind turbines. Shares are typically sold in $1000 \mathrm{kWh} /$ year blocks. The commune sells the turbine's output to the grid, receiving the mandated "fair" price from the local utility, as well as the environmental bonus (i.e., a complete pass through of the electricity consumption tax), and since November 1999, the special payment in compensation for low energy prices. A small portion of revenue is retained by the commune's management association for operation and maintenance costs, and the rest is passed along to investors on a pro rata basis.

One of the advantages of a real estate commune is its simplicity. A commune can typically be established by having each participating real estate owner fill out a standard legal form and submit it to the local real estate registrar. Legal counsel is seldom required. The participating real estate owners form a management association with officials elected from among their ranks to oversee the operation and management of the turbine. Bylaws specify how decisions will be made, as well as dates for annual meetings and other pertinent details.

\section{Financing}

Assuming an installed cost of $\$ 1000 / \mathrm{kW}$ (no capital investment subsidies) and a 25\% capacity factor, one share equal to $1000 \mathrm{kWh} /$ year costs roughly $\$ 450$. A $15 \%$ capital investment subsidy lowers per-share investment to about $\$ 390$. A household consuming $250 \mathrm{kWh} / \mathrm{month}$ on average and wishing to maximize the tax benefits of its investment would purchase three shares, for a total investment of $\$ 1170$. This level of investment (i.e., ranging from $\$ 390$ to $\$ 1170$ ) is quite modest, and is often funded out of personal savings.

For those whose savings are a bit thin, financing options do exist. The modest size of investment is usually within the means of existing lines of credit. Banks are also often willing to write loans specifically for this purpose, though shares in a communal wind turbine generally cannot be used as loan collateral, except to the extent that they raise the appraised value of the associated real estate, and therefore the amount of debt available to be borrowed against the real estate. Thus, 
most loans are based on an evaluation of personal credit-worthiness, rather than on the merits of the wind project (Helby 1998d, 1998f).

The commune itself rarely has problems raising enough capital to purchase a wind turbine, for two reasons. First, most communes are dominated by farmers, whose operations result in sizable electricity use, enabling the purchase of many more shares than a typical household (see Text Box 2, Glimminge, where the number of shares per owner ranged from 10 to 250). Second, while most real estate communes are strictly local for cultural reasons, geographic proximity to the communal resource is not a legal requirement; participating pieces of real estate can be distributed throughout the country. This geographic freedom expands the potential capital base accessible to the commune.

\section{Taxation}

As long as a commune member has not invested in more $\mathrm{kWh} /$ year than he consumes, the investment is taxed as a personal housing investment (like adding a garage to a house).

Revenues from electricity generation are not taxed, but the capital investment is subject to real estate and property taxes (each about 1.5\%) to the extent that it raises the assessed value of the property. Furthermore, if the investment was financed by some means other than personal savings, up to $30 \%$ of interest costs can be deducted (Helby 1998f, Langniss 1999).

If a commune member's investment exceeds his annual kWh consumption, the amount of production in excess of consumption is treated as a business investment, which introduces the complexity of depreciation and other rules. For this reason, it is normal for most commune members to limit the size of their investment to their expected consumption level. While tax optimization can therefore restrict the scalability or scope of projects undertaken by a real estate commune, the geographic freedom to look outside of the local area for investors potentially mitigates this constraint.

\section{Liability}

The liability of each shareholder in a real estate commune is limited to the amount invested.

\section{Liquidity}

An investment in a real estate commune is quite illiquid. The public or communal facility (i.e., the wind turbine) is legally considered to be an attachment to a number of individual parcels of real estate, in proportion to the number of shares purchased by each real estate owner.

Ownership of the turbine does not exist beyond ownership of the real estate to which it is attached; if the real estate is bequeathed or sold, the communal property (i.e., wind turbine) is transferred along with it. It is possible to re-register the shares to a different piece of real estate (i.e., with a different owner), but - in stark contrast to the initial ease of setting up a commune the process of re-registering shares is reported to be complicated and expensive, and the potential universe of "buyers" is limited to those who own real estate (Helby 1998d). Thus, an investment in a communally owned wind turbine is generally only as liquid as the real estate to which it is registered, and while it is probable that such an investment will add value to one's real estate (particularly if the turbine is physically located elsewhere), there is no guarantee that future buyers will value the investment correctly (or at all). 
Helby (1998d) points out that the characteristics of an investment in a real estate commune lead to a fairly narrow demographic segment of investors to whom such a scheme appeals: those who are unlikely to want to sell their wind turbine shares, are unlikely to sell their farms or property within the useful life of the project, and who are sufficiently well off so as to not anticipate needing to borrow against their share in the turbine. Successful middle-aged farmers and local wage earners with steady employment and a strong attachment to the local area may fit into this segment.

\section{TeXt BoX 2: Glimminge Wind PoWer Real Estate Commune}

In the first Swedish case study for the FIRE program (Helby 1998d), Peter Helby interviewed the two main farmers/promoters in the Glimminge Wind Power Real-Estate Commune, located in the coastal town of Höganäs in southern Sweden. ${ }^{1}$ The commune consists of 15 farmers and 4 individuals, all local people, who communally own a $500 \mathrm{~kW}$ Wind World turbine located in one of the farmer's fields. The project, which was completed in early 1995, received a 35\% capital investment subsidy from the government, with the remaining $65 \%$ of capital raised through the sale of 950 shares of $1000 \mathrm{kWh} /$ year, which equates to an expected capacity factor of about 22\%. Each share cost SEK 2500 ( \$320), and the number of shares per owner varies from 10 to 250 , depending primarily on each owner's energy consumption. The two main farmers promoting the project developed the project with the help of a Wind World sales agent; no legal or accounting services were used.

The majority of shares appear to have been financed primarily out of personal savings or money taken from existing lines of credit, though two local banks also offered dedicated loans of $10 \%{ }^{2}$ The two farmers/promoters deny any environmental motivation behind the project, and thought that the other owners shared their view of this investment solely as a good business opportunity. Compared to their other farm investments, the farmers did not view this investment as particularly risky, and even felt that the turbine reduced their risk by diversifying their farm operations. In addition, the farmers expected electricity prices to rise in the future as nuclear reactors are decommissioned. Electricity prices have since fallen to very low levels, and Swedish wind turbine production records indicate that the Glimminge turbine has on average generated roughly 5\% less than expectations (Swedish Wind Power Association, 2001).

${ }^{1}$ The author of this paper has also had the good fortune to tour this project and speak with the principal farmer in the commune.

${ }^{2}$ To the extent that any of the commune members made use of these loans, they must have expected the project to return in excess of $10 \%$. The two farmers/promoters interviewed thought that the loans were not widely used, but were valuable nonetheless as a financial "stamp of approval" on the expected success of the project.

\subsubsection{Vindkonsumföreningar (consumer cooperative selling to the utility)}

\section{Background}

Another common form of participatory ownership in Sweden that is likely to be more familiar to most people in the United States is the consumer cooperative. While Swedish wind cooperatives have traditionally sold their power to utilities, at least one cooperative has recently begun to sell wind power directly to its members nationwide at cost. Because the traditional model could hold some relevance to regulated areas of the United States and elsewhere, ${ }^{7}$ and because the

\footnotetext{
${ }^{7}$ In fact, the Toronto Renewable Energy Cooperative (TREC) has attempted to install a cooperatively-owned wind turbine using a structure quite similar to the traditional Swedish model, though couched in different terms. TREC has billed its approach as a "net billing" model, in which the utility treats the turbine as it would a net-metered installation, with the difference being that the turbine is centrally located instead of customer-sited, and is owned by many individuals. The mechanics of this and the local Swedish model are essentially the same. See Text Box 5.
} 
nationwide direct-sale model represents an innovative response to a competitive market, both models will be described below in detail, beginning with the traditional model.

\section{Operations (traditional model)}

The fundamental principle of most cooperatives is that any profit earned by the cooperative over the course of the year is distributed to each cooperative member in proportion to the volume of business that member has conducted with the cooperative. Thus, dividends are distributed based on the level of patronage, rather than on the level of investment. In practice, however, it is possible to match the level of patronage with the level of investment simply by limiting each member's investment to the amount of electricity he expects to consume. In this way, each cooperative member earns the same return on investment.

Mechanically, the cooperative form of wind ownership is more or less identical to that described for real estate communes, though it does involve some legal nuances concerning the utility's role that bear some explanation. As with the real estate commune, individuals band together into a consumer cooperative and pool their capital to install a wind turbine. The cooperative "sells" the turbine's output to the utility at the agreed upon feed-in tariff, though for legal purposes, this "sale" is regarded as a transfer of power through the utility to the cooperative members. ${ }^{8}$ Throughout the year, each cooperative member is billed as normal by the local distribution utility for his electricity consumption. At the end of the year, once the actual output of the cooperative wind turbine is known, the cooperative calculates the amount of energy each member has "purchased" from the cooperative, and distributes patronage dividends, consisting of the feed-in tariff plus the environmental bonus (and since late 1999, the special payment in compensation for low electricity prices). ${ }^{9}$

As long as each cooperative member's consumption matches or exceeds his level of investment, return on investment will be equal for all cooperative members, and any excess consumption is simply considered to have been purchased from the utility rather than the cooperative. If a member's consumption falls short of his level of investment, however, then that member forgoes a share of the profits, and the cooperative must decide what to do with the excess energy. Options include distributing the kWh pro rata to other members who have sufficient excess consumption to absorb it, or else treating it as a sale to a third party (i.e., non-member), in which case it will be distributed to all members on a taxable basis.

\section{Financing (traditional model)}

Shares in a cooperative are structurally no different from shares in a real estate commune: one share of $1000 \mathrm{kWh} /$ year usually sells for $\$ 450$ or less (depending on the availability of capital investment subsidies), and a household using $250 \mathrm{kWh} /$ month on average that seeks to maximize the tax benefits of its investment will purchase three shares. While this level of investment is

\footnotetext{
${ }^{8}$ This treatment is necessary to justify the cooperative as a consumer cooperative.

${ }^{9}$ There are indications that in the early days of Swedish wind cooperatives (i.e., prior to the 1996 deregulation law), some utilities, perhaps for the sake of simplicity or goodwill, simply passed the retail rate through to cooperative members (i.e., set the feed-in tariff equal to the retail rate less distribution charges), in effect creating an aggregate "net metering" program, in which the generator is not located on site, but rather at some central location (Helby 1998e). This is the same model that the Toronto Renewable Energy Cooperative has tried to replicate.
} 
often within the reach of personal savings, those households wishing to finance their shares can access the same options as the real estate commune: personal lines of credit and personal loans.

Despite the ready availability of personal financing options, local cooperatives may have a difficult time raising sufficient capital for a wind project, for a number of reasons. First, because the local distribution utility plays an integral role as transfer agent, participation is limited to electricity consumers living in the utility's service territory. Second, the amount of investment is limited to each member's consumption. In fact, because a member forfeits some profits if his consumption falls below his level of investment, members have an economic incentive to underinvest in the cooperative, leaving a margin of safety. This is especially true if a member is considering efficiency improvements in the future, such as switching from electric to district heating. ${ }^{10}$ Finally, large investors such as businesses have few incentives to join a cooperative: the tax advantage disappears for businesses, given that cheap power will increase taxable profits just as much as does earned revenue, and the democratic cooperative principle of "one member one vote" prohibits large investors from wielding influence in proportion to the size of their investment, a fact which may not sit well with some businesses.

As a result of these limitations, cooperatives may have a particularly difficult time raising a sufficient amount of capital to develop a wind project (as compared to a real estate commune, which is not subject to such tight geographic constraints). In fact, the third Swedish case study prepared by Peter Helby for the FIRE project details a project owned by a partnership consisting of a consumer cooperative and the country's largest utility, Vattenfall. Vattenfall was approached by the cooperative to rescue the project after the cooperative was only able to raise $20 \%$ of the necessary capital (Helby 1998e). A review of membership in other cooperatives indicates that partial utility ownership is a fairly common event (Wizelius 1999a, 1999b). Such capital shortfalls may be further exacerbated as wind turbine capacities continue to increase; the output from a 1.6 MW turbine over the course of a year may exceed the energy needs of the local investor pool, thereby limiting the profitability of the cooperative approach.

\section{Taxation (traditional model)}

The cooperative itself is not subject to tax - any taxable profits are assessed at the level of individual members. For tax purposes, however, distributed profits from a cooperative are not treated as income, but rather as adjustments (i.e., rebates) to the price paid to the cooperative (Helby 1998e). Thus, patronage dividends are tax-free. Members only pay taxes on income from power sales to third parties (described under "operations") and on accumulated capital in the cooperative, which is taxed at a 30\% rate. Since sales to non-members will be a rare event, and the amount of accumulated capital will most likely be small (i.e., enough to cover O\&M expenses for the year), investments in wind cooperatives are essentially tax-free. This has large benefits in a country with marginal income tax rates that range between 30\% and 56\% (Langniss 1999).

\section{Liability (traditional model)}

The liability of a cooperative member is limited to the amount invested.

\footnotetext{
${ }^{10}$ It could be argued that cooperative members not only have an incentive to under-invest, but also to over-consume (or at least not to conserve), as conservation may reduce consumption below the optimal level for return on investment. See Helby (1995) for a discussion of the irrationality of linking subsidies to consumption.
} 


\section{Liquidity (traditional model)}

Because shares are not tied to the land, investment in a wind cooperative is generally much more liquid than an investment in a real estate commune. Nevertheless, in comparison to most alternative investments, an investment in a wind cooperative is still fairly illiquid. Shares are not listed on an exchange, making it potentially difficult to find a buyer and determine an agreeable price. The cooperative will, however, usually provide a crude market-making service, in which it keeps an active list of those looking to buy and sell shares. The fact that membership is restricted to the local service territory, however, limits the universe of potential buyers.

\subsubsection{Vindkonsumföreningar (consumer cooperative selling directly to members)}

\section{Background (direct sale model)}

Swedish wind cooperatives have traditionally sold their power to the local utility instead of directly to their members in order to avoid having to take responsibility for balancing their members' loads with a sufficient amount of supply at any given moment. Given that up until late 1999 utilities had paid reasonable rates for wind power, there was little impetus for cooperatives to search out better markets or take on "balance of responsibility" duties in order to sell directly to members (Helby 1998f). With the precipitous drop in wind feed-in tariffs following the opening of the residential market to competition, however, the incentive to bypass the utility and "step outside of the market" has grown considerably. In response, a cooperative and a distribution utility have joined together in an innovative partnership that promises to overcome many of the constraints facing local cooperatives in Sweden (and detailed in the previous section on traditional cooperatives).

For a small fee of SEK 0.005/kWh $(\sim 0.05 \$ / \mathrm{kWh})$, Falkenberg Energi, a distribution utility, has agreed to provide "balance of responsibility" service to Sveriges Vindkraftkooperativ (Sweden Wind Cooperative) on a nationwide basis, allowing Sveriges Vindkraftkooperativ to sell wind power directly to members throughout Sweden. ${ }^{11}$ This agreement in effect creates Sweden's first nationwide cooperative, thereby removing the constraints of local ownership that have limited the scalability of the traditional cooperative model. Industry observers expect the Falkenberg model to double the number of cooperative wind investors in Sweden within a year or two, and Sveriges Vindkraftkooperativ's own goal is to increase the number of community wind investors in Sweden from about 15,000 today to 100,000 by 2005 (Envall 2001).

Since the Falkenberg model is the first of its kind, the elements of this model will be described in terms specific to the Falkenberg/Sveriges Vindkraftkooperativ partnership, rather than generically.

\section{Operations (direct sale model)}

To participate, households must become Falkenberg Energi customers and invest SEK 4000 for each $1000 \mathrm{kWh} /$ year block of wind power. ${ }^{12}$ Sveriges Vindkraftkooperativ invests the funds in

\footnotetext{
${ }^{11}$ Prior to the opening of the residential market in November 1999, Falkenberg had been providing this service for Sveriges Vindkraftkooperativ on a local basis, within the Falkenberg service territory.

12 The prospect of increasing their customer base in the newly competitive market is one motivation behind Falkenberg Energi's willingness to participate.
} 
wind turbines located at promising sites throughout Sweden, and then sells the wind power directly to its members at the low generation rate of only $18 \mathrm{SEK} / \mathrm{MWh}(\sim 0.18 \$ / \mathrm{kWh})$. This trivial rate is made possible by Sweden's generous subsidies, which the cooperative rolls into its price rather than refunding at the end of the year. ${ }^{13}$ This strategy has an important effect on the amount of value-added tax (VAT) that members pay: by reducing the generation price from a normal level of $215 \mathrm{SEK} / \mathrm{MWh}$ to only $18 \mathrm{SEK} / \mathrm{MWh}$, the cooperative saves its members an additional 49 SEK/MWh in VAT (Sweden has a 25\% VAT). This VAT effect, along with not having to pay the utility's margin (i.e., buying at retail and selling at wholesale), are the two main advantages of selling power directly to cooperative members, and are how the cooperative member earns a return on investment - by paying less than a non-member for electricity.

Table 3 compares a typical non-member's bill for $1000 \mathrm{kWh}$ of electricity (i.e., one share) to that of a member of a real estate commune or traditional consumer cooperative (the economics of the two are basically the same), as well as a Falkenberg/Sveriges Vindkraftkooperativ member. The final column shows that by lowering the retail rate its members pay, the Falkenberg model greatly reduces the amount of VAT as well, which brings its per-share return relative to a nonmember to $9.9 \%$, exceeding the $9.1 \%$ return of a traditional cooperative or real estate commune that sells power to the utility rather than to its members.

Table 3. Comparison of Swedish Cooperative Models to a Non-Member (SEK/MWh)

\begin{tabular}{|c|c|c|c|c|}
\hline & & Non-Member & $\begin{array}{c}\text { Traditional } \\
\text { Model }\end{array}$ & $\begin{array}{c}\text { Falkenberg } \\
\text { Model }\end{array}$ \\
\hline & Wind power sold to: & $N A$ & Utility & Co-op Member \\
\hline Payment & Generation & 215 & 215 & 18 \\
\hline Payment & Electricity tax & 181 & 181 & 181 \\
\hline Payment & Distribution & 150 & 150 & 150 \\
\hline Payment & VAT (25\%) & 137 & $\underline{137}$ & $\underline{87}$ \\
\hline & Total payment / MWh & 683 & 683 & 436 \\
\hline Receipt & Generation credit & 0 & 140 & 0 \\
\hline Receipt & Low price compensation & 0 & 90 & 0 \\
\hline Receipt & Environmental bonus & 0 & 181 & $150^{*}$ \\
\hline Receipt & Cooperative O\&M costs & $\underline{0}$ & (48) & $\underline{0}$ \\
\hline & Total Income / MWh & $\mathbf{0}$ & 363 & 150 \\
\hline & Net payment / MWh & 683 & 319 & 286 \\
\hline \multicolumn{3}{|c|}{ Co-op advantage (over non-member) per MWh: } & 363 & 396 \\
\hline \multicolumn{3}{|c|}{ \% Return (Co-op advantage / 4000 SEK): } & $9.1 \%$ & $9.9 \%$ \\
\hline
\end{tabular}

*The environmental bonus paid by Sveriges Vindkraftkooperativ includes the refund of the electricity tax (i.e., the standard environmental bonus) less O\&M costs, as well as the proceeds from selling $15 \%$ of each turbine's output to Falkenberg. In order to provide a cushion for low wind years, when production could fall as low as $15 \%$ below normal, the cooperative has sold only $85 \%$ of each turbine's expected output. In normal or windy years, any production in excess of what has been sold to cooperative members will be sold to Falkenberg (under the same terms as the traditional model). Thus, the 150 SEK/MWh environmental bonus from Sveriges Vindkraftkooperativ is approximate, and will vary slightly depending upon on how windy of a year it is (Envall 2001).

\footnotetext{
${ }^{13}$ In fact, Mats Envall, president of Sveriges Vindkraftkooperativ, was quoted as saying "We could probably sell for zero, but I don’t think the politicians would like it.” (Samstag and Wizelius 2000)
} 
Financing (direct sale model)

An investment of 4000 SEK ( $\$ 400$ ) entitles a cooperative member to $1000 \mathrm{kWh}$ of wind power per year. While the means of financing a personal investment in the cooperative do not differ from those previously discussed in the real estate commune and traditional cooperative models (i.e., personal savings, lines of credit, and bank loans), the total amount of capital available to the nationwide cooperative is vastly different. With the entire nation now eligible to become Sveriges Vindkraftkooperativ members, the cooperative model is no longer limited by the size of the local investment pool. Furthermore, individuals living in areas where local wind is not feasible - such as in cities or low-wind-speed areas - can now become a wind cooperative member. This expansion in the amount of capital will potentially allow the cooperative to achieve greater economies of scale.

Taxation (direct sale model)

Taxation issues are no different from the traditional model - as long as an individual consumes as much or more electricity than his share produces, production is tax-free. This distinction is somewhat moot, since Sveriges Vindkraftkooperativ distributes profits through cut-rate power rather than through patronage dividends. Thus, a member only profits on power that he consumes, creating a strong incentive not to over-invest.

Liability (direct sale model)

As with the two other community models in Sweden, financial liability is limited to the amount invested.

Liquidity (direct sale model)

A share in Sveriges Vindkraftkooperativ is perhaps the most liquid community-owned investment among any of the models examined in any country: members may withdraw the full amount of their investment at any time (subject to a minimal delay if the amount is large). The cooperative maintains a cash fund of sufficient size to cover expected withdrawals. As is standard procedure for most cooperative investments, where shares are traditionally traded or redeemed only at par, no interest is paid on investments in Sveriges Vindkraftkooperativ.

\subsubsection{Looking Ahead}

For the moment, community-owned wind in Sweden is energized. The nationwide cooperative model pioneered by Falkenberg Energi and Sveriges Vindkraftkooperativ promises to inject significant amounts of new capital into the wind power market, counteracting the potential for stagnation as eligible and interested investors for new local schemes become increasingly scarce in some of the windier parts of the country. Like its neighbor Denmark, however, Sweden too is moving towards a renewable portfolio standard based on a system of tradable green certificates (TGCs). While details have been scarce, the government hopes to have the new system in place by 2003. Sveriges Vindkraftkooperativ is confident that it will be able to operate in the new environment; indeed, its relationship with Falkenberg Energi (a utility) may prove to be a valuable asset as Sweden moves to a more market-based system of support. In the meantime, despite the considerable uncertainty over how valuable a revenue source TGCs will be, there appears to be little market risk in investing in Sveriges Vindkraftkooperativ, given that a member can simply withdraw his investment at any time without penalty. 


\subsection{Germany}

\subsubsection{Background and Wind Development Trends}

With over $6000 \mathrm{MW}$ installed capacity, Germany is - by more than $3000 \mathrm{MW}$ - the world leader in wind energy. Lacking a strong wind resource, Germany owes its success to the attractive Stromeinspeisungsgesetz, or electricity feed-in law (EFL), introduced in 1991. By ensuring a stable and profitable market for wind projects, the EFL has catapulted Germany to the forefront of installed capacity, and encouraged the development of a strong wind turbine manufacturing base, second only to that in Denmark. Figure 4 shows the accelerating growth of wind power in Germany.

Figure 4. Wind Development in Germany

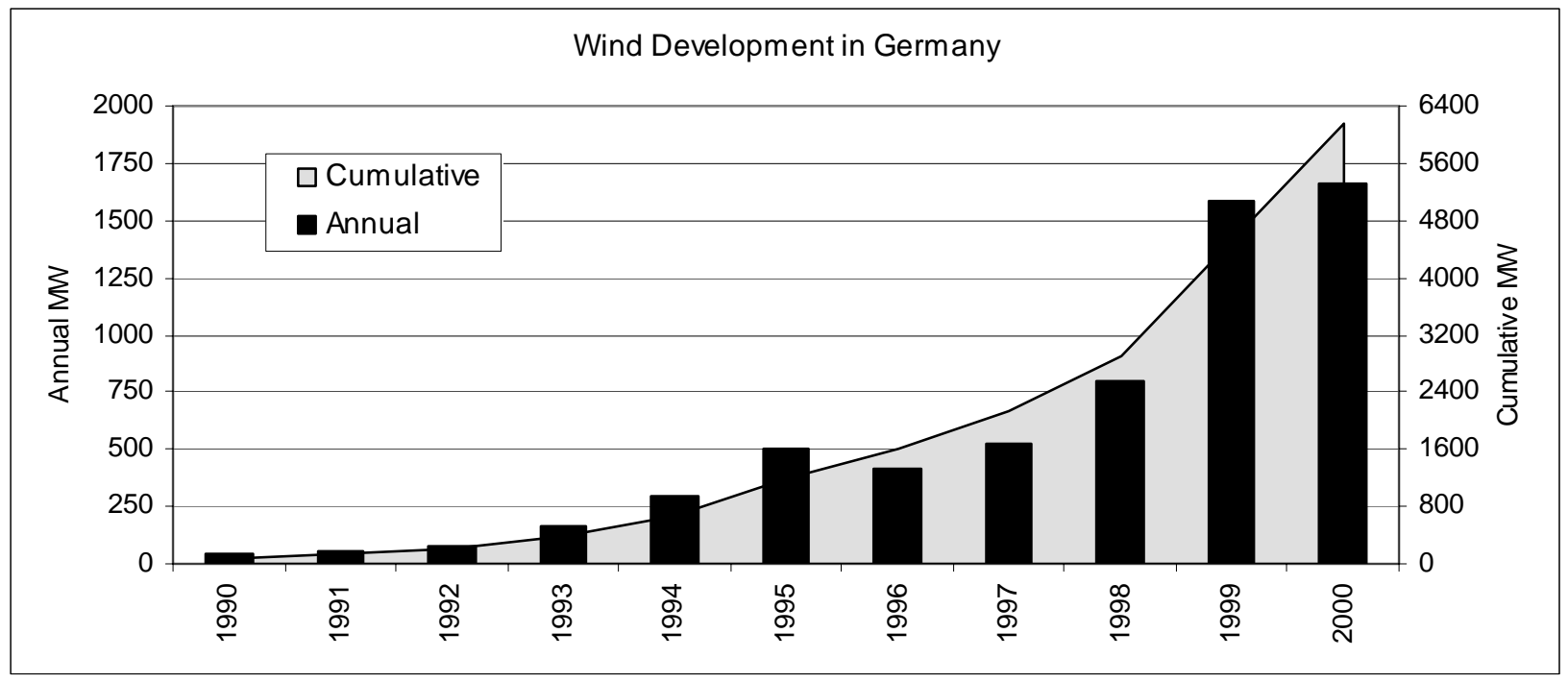

The EFL has also made community wind energy an attractive proposition: more than 100,000 Germans either individually or jointly own wind turbine (Ecotec 1999). Data from the Deutsche Ausgleichsbank (DtA), which has debt financed roughly $90 \%$ of all German wind projects, indicate that roughly three quarters of all German wind capacity is community-owned (Stein 2001). ${ }^{14}$ Figure 5 shows the changing share of DtA loan volume to various ownership types from 1990 to 2000, as well as the aggregate total for the entire period. ${ }^{15}$ The most dramatic shift in ownership has been from sole proprietors, comprised largely of individual farmers, to limited partners, comprised mainly of wealthy individuals. This shift reflects the "commercialization" of German wind development, as well as the increasing size of wind projects in Germany.

\footnotetext{
${ }^{14}$ Specifically, the DtA data shows that 75\% of the DtA's loan volume to wind projects between 1990 and 2000 was to jointly-owned projects (63\% to limited partnerships, and 12\% to general partnerships of sole proprietors (GbR)). Assuming a similar debt/equity ratio across projects, loan volume will roughly equate to installed capacity.

${ }^{15}$ A GbR is a general partnership consisting of sole proprietors. This ownership structure most likely reflects individual farmers pooling their resources to install a wind project.
} 
Figure 5. Percentage of DtA Loan Volume to Various Ownership Types

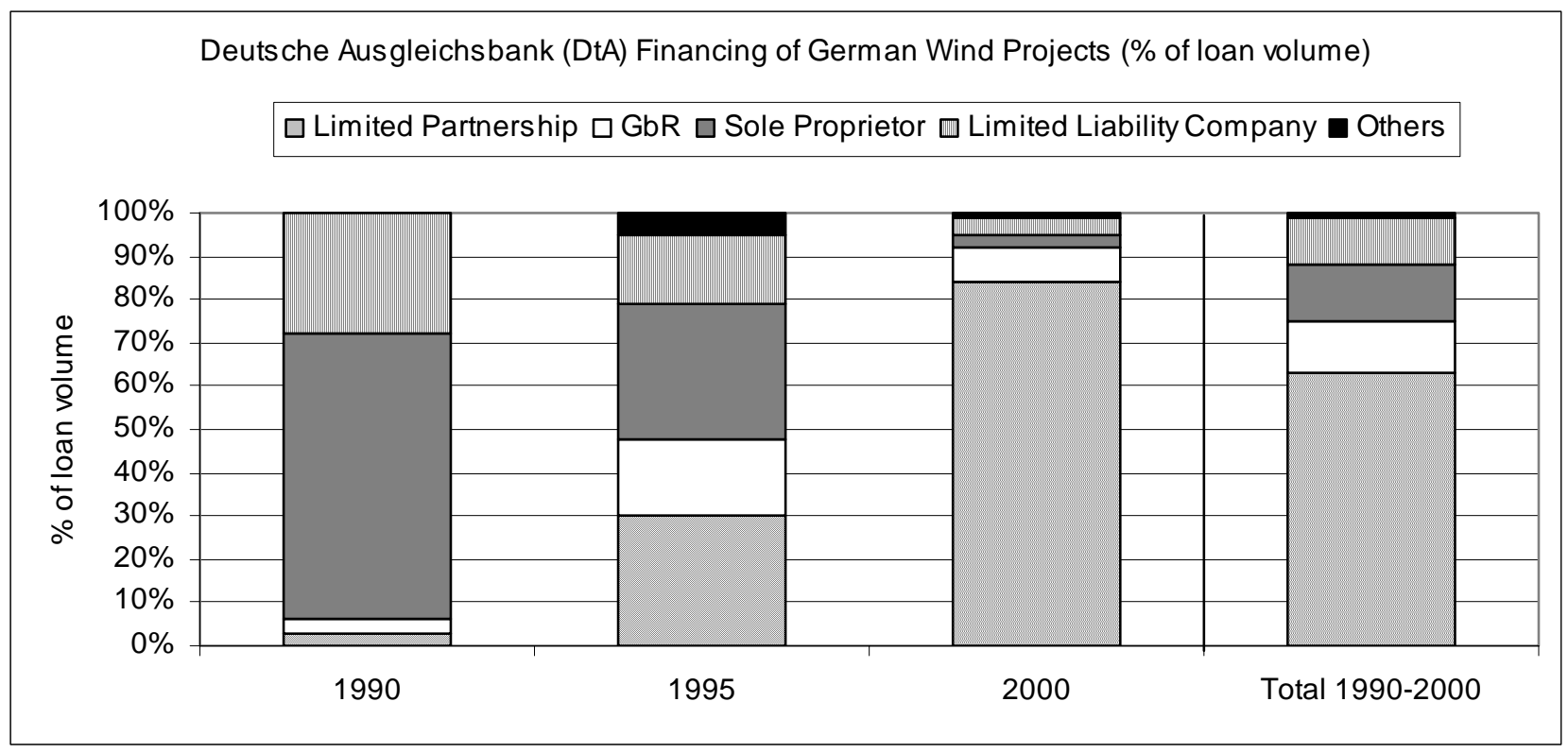

\subsubsection{Support for Wind Power}

\subsubsection{Capital Support}

There are currently no capital investment subsidies at the national level for wind turbines, though regional or state governments may offer investment subsidies. The national $100 \mathrm{MW}$ Wind Program and its successor, the $250 \mathrm{MW}$ Wind Program, had previously subsidized wind turbine investments up to 60\% (Langniss 1999), but these programs stopped accepting new applications at the end of 1995.

\subsubsection{Production Support}

Since 1991, the EFL has been the primary driver behind Germany's strong growth in installed wind capacity. Under the EFL, German utilities have been required to pay wind generators $90 \%$ of the average retail electricity price during the penultimate year for all customer classes across Germany. Table 4 shows the prices paid to wind generators since 1991.

Table 4. Prices Paid to Wind Generators Under the EFL (DEM/kWh)

\begin{tabular}{|c|c|c|c|c|c|c|c|c|}
\hline 1991 & 1992 & 1993 & 1994 & 1995 & 1996 & 1997 & 1998 & 1999 \\
\hline 0.1661 & 0.1653 & 0.1657 & 0.1693 & 0.1728 & 0.1721 & 0.1715 & 0.1679 & 0.1652 \\
\hline
\end{tabular}

These feed-in tariffs have attracted significant wind development, particularly to the northern coastal regions of Germany that have the best wind resource, placing a disproportionately large share of the above-market costs of the EFL on northern utilities and their captive ratepayers. In an attempt to curb the magnitude of this inequity, the government amended the EFL in 1998 to allow utilities to opt out of any further purchase obligations once EFL-supported generation in a service territory reached $5 \%$ of total generation in that territory. 
In April 2000, the government replaced the EFL with the Erneuerbare-Energien-Gesetz or EEG (also known as the "Act on Granting Priority to Renewable Energy Sources" or the "Renewable Energy Sources Act”). The EEG is essentially an updated version of the EFL, intended to bring Germany's system of feed-in tariffs into compliance with EU law, address the cost inequity issue in a more sustainable manner than did the $5 \%$ cap, and ensure a stable investment climate for renewables as Europe liberalizes its electricity markets. Specifically, the EEG abolished the 5\% cap and replaced it with a cost-sharing mechanism that distributes the above-market costs of feed-in contracts equally among all German ratepayers. Utility-owned wind projects, which had been ineligible for EFL support unless sited in another utility's service territory, are placed on equal footing with independent renewable generators under the EEG. Finally, the EEG decoupled the feed-in tariff from the retail rate, and instead set a fixed feed-in tariff guaranteed for 20 years.

New projects receive $0.178 \mathrm{DEM} / \mathrm{kWh}$ for an initial period of at least 5 years for onshore plants, and nine years for offshore plants that become operational prior to 2007. At the end of the initial period, a wind plant that has generated at least $150 \%$ of a "reference yield" (i.e., calculated as the amount of production at a generic site with average wind speeds of $5.5 \mathrm{~m} / \mathrm{s}$ at 30 meters hub height) will receive $0.121 \mathrm{DEM} / \mathrm{kWh}$ for the next 15 years. Any wind plant that has generated less than $150 \%$ of the reference yield will have its initial high-tariff period extended by 2 months for every $0.75 \%$ that its actual production is less than $150 \%$ of the reference yield. For example, if at the end of five years a wind plant has produced $135 \%$ of the reference yield, its high-tariff period will be extended for 40 months, after which it will receive the lower tariff of 0.121 $\mathrm{DEM} / \mathrm{kWh}$ for the remainder of the 20-year period. This mechanism is meant to encourage development at inland sites where the wind resource is generally inferior to that in coastal areas.

To promote cost reductions, the EEG will lower the feed-in tariff paid to new projects by $1.5 \%$ each year starting in 2002. These reductions affect only new projects; the tariff for existing wind plants is fixed for the entire 20-year period (notwithstanding the "reference yield" variations) at wherever the tariffs stand in the year of commissioning.

In March 2001, the European Court of Justice declared that the EEG is in line with European Union law concerning the move towards a single electricity market. The court found that since its ultimate costs are borne by electricity consumers, the EEG does not represent state aid to renewables, and therefore does not violate the EU electricity market directives.

\subsubsection{Interconnection}

As in Denmark and Sweden, the generator pays the cost to connect to the closest acceptable point on the grid, and the grid operator is responsible for any further expenses involving grid reinforcement or interconnection at a more distant location. This arrangement was in effect under the EFL, and has not changed under the EEG. 


\subsubsection{Community Ownership Models}

Traditional wind cooperatives are rare in Germany, due to high start up costs as well as the existence of a more attractive tax-advantaged alternative - the GmbH \& Co. KG (Langniss 1999).

\subsubsection{GmbH \& Co. KG (limited partnership with a limited liability company as general partner)}

Background

This is considered to be the most common form of community wind ownership in Germany.

\section{Operations}

In this model, a wind developer initially incorporates his business as a limited liability company $(\mathrm{GmbH})$. For each project undertaken, the developer forms a limited partnership (KG) with his limited liability company as general partner and individual investors as limited partners. The developer may target local investors, but usually does not restrict share ownership to a particular area, and one study indicates that local residents typically make up only 20-30\% of all limited partners (Ecotec 1999). Project revenues are distributed proportionate to the level of each partner's investment. Even though the high feed-in tariff allows most projects to turn a profit right from the start, dividends are generally not paid during the first two years, and instead are diverted into a maintenance or reserve fund.

This model is valuable to the developer in several ways. First, the cost of setting up a limited liability company $(\mathrm{GmbH})$ is fairly high, while it is relatively easy and inexpensive to form a partnership (KG). Thus, this model allows developers to spread the high costs of $\mathrm{GmbH}$ formation over multiple projects and partnerships. Second, by offering shares to the public, this model allows developers to liquidate their part-ownership in one project in order to finance another (Ecotec 1999), and also potentially reduces planning objections.

\section{Financing}

A GmbH \& Co. KG must raise a minimum share capital of DEM 50,000 - not a problem with wind projects - and the minimum contribution per member is DEM 500. In practice, however, shares are often offered in minimum increments of DEM 20,000 ( \$10,000) - significantly larger than in other European countries. This disparity reflects the relative commercial nature of wind projects in Germany; the EFL tariffs and tax advantages are high enough in Germany to attract a different investor class - those motivated primarily by profits, rather than (or perhaps in addition to) environmental or community concerns. Since a GmbH \& Co. KG ownership structure is not linked in any way (i.e., neither legally nor by tax advantages) to an individual's electricity consumption, wind projects in Germany tend to be larger, with larger minimum investment thresholds, than is the case in the more cooperative-oriented countries such as Sweden and Denmark. Projects of 10-20 MW that are 25\% equity-financed primarily by individuals are not uncommon in Germany.

The ready availability of low-cost debt financing also favors larger projects. The Deutsche Ausgleichsbank (DtA) is a government-owned bank that distributes funds from the European 
Recovery Program (a vestige of the post-war Marshall Plan) and the Environment Program to wind projects in the form of "soft" loans that average 1-2\% below market rates. Up to $100 \%$ of the cost of a project can be financed in this manner, though a mix of $75 \%$ debt/ $25 \%$ equity is more common (Harrison and Milborrow 2000). Almost all German wind projects receive DtA financing - in 1999, $1450 \mathrm{MW}$ of the $1600 \mathrm{MW}$ installed (or 90\%) received DtA financing (Harrison and Milborrow 2000). A similar pattern held in 2000 (Stein 2001). The combination of below-market financing from the DtA and above-market returns from attractive feed-in tariffs and favorable tax laws has favored larger, highly-leveraged projects.

\section{Taxation}

A GmbH \& Co. KG that is considered a private partnership pays no corporate tax - each partner is taxed at the individual level. Furthermore, partners in a private partnership have historically been able to offset losses from the depreciation of a wind share against all other forms of taxable income, making investments in a wind fund a popular tax haven for wealthy Germans. A relatively attractive 10-year depreciation schedule was in effect until July 1997, when the government extended it to 12 years. Recently, the government has announced plans to extend the depreciation period beyond 12 years, and to require that losses only be offset against income from the same investment, rather than against all forms of income. The potential removal of favorable tax status has had a chilling effect on wind financing in Germany, counterbalancing some of the optimism engendered by the new EEG law (Knight 2000).

\section{Liability}

Limited partners are liable for the full amount of their investment. The general partner has unlimited liability, but since the general partner is most often the developer's limited liability company $(\mathrm{GmbH})$, personal liability is limited.

\section{Liquidity}

Shares can be transferred to other partners, or new partners. Some transfers may require the agreement of the other partners.

\subsubsection{Looking Ahead}

Germany's installed wind capacity is expected to continue to grow at record pace, with between 1800 and 2000 MW of new capacity forecast for 2001 (Knight 2001). Developers are confident that the new EEG law - recently given the green light by the European Court of Justice - is lucrative enough to enable them to restructure their wind fund investment schemes to compensate for the adverse change in tax laws (Knight 2000). Thus, unlike in Denmark, Sweden, and the UK, where community-owned wind schemes are grappling with the uncertainties created by a policy shift towards renewable portfolio standards, community-owned wind in Germany is likely to encounter smooth sailing in the foreseeable future. 


\subsection{The United Kingdom}

“'Your own pigs don't smell' say the Danes” - Network for Alternative Technology and Technology Assessment (NATTA 2001)

\subsubsection{Background and Wind Development Trends}

The UK has by far the best wind resource in Europe (both on- and off-shore), yet ranks a distant fifth among European countries in terms of installed wind capacity. The roughly $400 \mathrm{MW}$ of wind capacity currently on-line in the UK pales in comparison to the 6,000 MW in Germany and the more than 2,000 MW in both Denmark and Spain. The UK's poor showing can be attributed in part to the relative lack of government support for wind energy (and the form that support takes), as well as to planning difficulties brought on by an often intense opposition on the part of British citizens to the visual intrusion of wind turbines on the landscape. To some degree, the two causes are related (see Text Box 3).

Figure 6 shows annual and cumulative installed wind capacity in the UK, broken out by community-owned and all other forms of development. Of the roughly $410 \mathrm{MW}$ of wind capacity installed in the UK at the end of 2000, only 3.4 MW from two projects in 1997 and 1998 were community-owned.

Figure 6. Wind Development in the UK (Community-owned and Other)

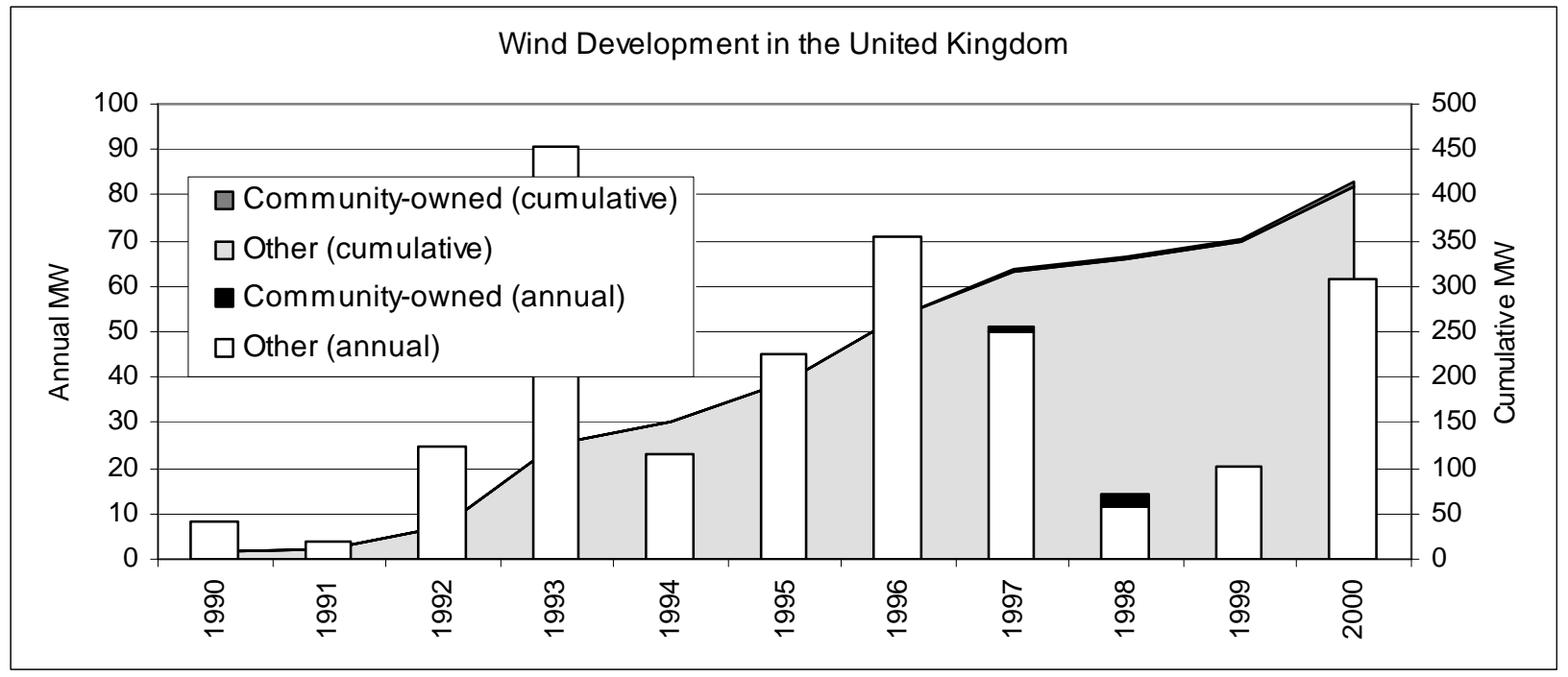

\subsubsection{Support for Wind Power}

Unlike its European neighbors in Denmark, Sweden, Germany, and Spain, all of which have offered a variety of support mechanisms for wind power throughout the 1990s (including attractive feed-in tariffs and tax incentives), the U.K. has instead relied almost entirely on a competitive tendering process known as the Non-Fossil Fuel Obligation (NFFO) to support renewable energy. 


\subsubsection{Capital Support}

The NFFO support mechanism provides only production subsidies, not capital investment subsidies.

\subsubsection{Production Support}

Between 1990 and 1998, renewable generators were able to bid for above-market contracts in five NFFO auctions intended to result in a total of $1500 \mathrm{MW}$ of declared net capacity (DNC). ${ }^{16}$ The UK's 12 regional electric companies (RECs) were required to purchase the output of any project awarded an NFFO contract, and were refunded the difference between the NFFO price and the market price via a surcharge on electricity consumption known as the fossil fuel levy. NFFO1 and NFFO2 offered contracts that expired at the end of 1998, while NFFO3, 4, and 5 offered 15-year contract-terms, with the awarded price indexed to inflation. Within each auction there were separate "bands" for different renewable technologies (e.g., wind, landfill gas, etc.), and in the last three rounds there have also been sub-bands for small wind projects. ${ }^{17}$ Table 5 shows the results for wind power in NFFO1-5. Two points worth noting are that only a small fraction of awarded capacity has actually been built to date, and the large drop in prices between NFFO2 and NFFO3 reflects, in part, the shift to 15-year contracts.

Table 5. Winning Bids in NFFO Wind Bands

\begin{tabular}{|c|c|c|c|c|c|c|c|}
\hline & Year & NFFO Band & $\begin{array}{l}\text { Number of } \\
\text { Awards }\end{array}$ & $\begin{array}{c}\text { Total Capacity } \\
\text { (MW DNC) }\end{array}$ & $\begin{array}{l}\text { Min. Bid } \\
(\mathrm{p} / \mathrm{kWh})\end{array}$ & $\begin{array}{c}\text { Max. Bid } \\
(\mathrm{p} / \mathrm{kWh})\end{array}$ & $\begin{array}{l}\text { Avg. Bid } \\
(\mathrm{p} / \mathrm{kWh})\end{array}$ \\
\hline NFFO1 & 1990 & All Wind & 9 & 12.4 & 5.75 & $10.0^{*}$ & \\
\hline NFFO2 & 1991 & All Wind & 49 & 82.4 & 6.39 & $11.0^{*}$ & 9.97 \\
\hline \multirow{2}{*}{ NFFO3 } & \multirow[b]{2}{*}{1994} & Large Wind $^{* *}$ & 31 & 145.9 & 3.98 & 4.80 & 4.32 \\
\hline & & Small Wind $^{* *}$ & 24 & 19.7 & 4.49 & 5.99 & 5.29 \\
\hline \multirow{2}{*}{ NFFO4 } & \multirow{2}{*}{1997} & Large Wind & 48 & 330.4 & 3.11 & 3.80 & 3.53 \\
\hline & & Small Wind & 17 & 10.4 & 4.09 & 4.95 & 4.57 \\
\hline \multirow{2}{*}{ NFFO5 } & \multirow{2}{*}{1998} & Large Wind & 33 & 340 & 2.43 & 3.10 & 2.88 \\
\hline & & Small Wind & 36 & 28 & 3.40 & 4.60 & 4.18 \\
\hline
\end{tabular}

*All NFFO1 and NFFO2 contracts were awarded at the highest accepted bid, while NFFO3-5 contracts were awarded on a pay-as-bid basis.

*** The threshold distinguishing large and small wind projects was 1.6 MW DNC in NFFO3, 0.768 MW DNC in NFFO4, and 0.995 DNC in NFFO5.

\subsubsection{Interconnection}

Unlike Denmark, Germany, and Sweden, the UK has not yet defined the responsibilities of the various interested parties with respect to interconnection (Ecotec 1999). Projects that have secured NFFO contracts can be reasonably assured that they will be interconnected, since the RECs are required to purchase their output. The cost of interconnection, however, as well as the cost allocation, remains somewhat of an unknown. Projects without NFFO support face greater risks with respect to interconnection.

\footnotetext{
${ }^{16}$ Declared net capacity (DNC) is the amount of baseload capacity required to produce an equivalent amount of energy over a year. Thus, a 4 MW wind farm with a $25 \%$ capacity factor would have a DNC of $1 \mathrm{MW}$.

${ }^{17}$ NFFO3 introduced a sub-band for wind projects of less than 1.6 MW DNC. The threshold was reduced to 0.768 MW DNC for NFFO4, and then increased to 0.995 MW DNC for NFFO5.
} 
For an excellent discussion of the NFFO process and its impact on wind development in the UK, see Mitchell (2000). Text Box 3 summarizes some of her findings.

\section{Text Box 3: The NFFO's Impact on Wind Development in the UK}

While it has been widely lauded as a competitive mechanism that encourages efficient cost reductions in renewables, the NFFO process is perhaps equally criticized for its effect on wind development in the UK. Most of the criticisms stem from the government's obsessive focus on reducing costs, and the intense competition for NFFO contracts. As Mitchell (2000) reports, the government's commitment to reduce the average price per kWh of each successive order essentially set the average price for a given technology in the previous order as a benchmark that all bidders seeking contracts in the following order must beat. This myopic focus on declining costs, along with several NFFO design features, drove developers to almost desperate measures in order to secure a contract. For example, the lack of a non-performance penalty in combination with a lengthy development period (4 years for NFFO3 and 5 years for NFFO4 and NFFO5) encouraged generators to bid speculatively based on expectations of declining technology costs. To further increase their chance of securing a contract, developers naturally looked to the strongest wind sites - which in the UK often coincide with prominent features in the landscape - rather than to sites that were more suitable for wind development and therefore more likely to receive planning permission. This practice eventually led to a country-wide anti-wind backlash and a rash of permit denials: between September 1991 and December 1993, 9 of the 12 wind farm proposals that went before planning inquiries were approved, while between January 1994 and early 1999, only 2 of 18 inquiries resulted in approval (NATTA 1999).

Further exacerbating the planning difficulties was the fact that many of the developers were seen as outsiders, invading the local landscape. This reputation is partly deserved: the severe competition for NFFO contracts favored developers with the resources to finance their projects on balance sheet instead of by more expensive forms of project finance (Langniss 1999). Since it is usually only the large, well-established developers - some based overseas - that have the wherewithal to employ corporate finance, the local developer usually loses out. Partly in response to this criticism, NFFO3 introduced a small wind band for projects under 1.6 MW DNC. Even so, some have argued that the involved process of submitting an NFFO bid is far too cumbersome for small projects, in which the high transaction costs make up a large portion of total project costs (assuming a contract is secured, which is a risk in and of itself).

Thus, compared to the secure and guaranteed feed-in tariffs offered in other European countries, the NFFO process is seen as being generally unfriendly to community wind. And with large projects regularly running up against planning roadblocks, wind development in the UK has lagged behind its European neighbors.

\subsubsection{Community Ownership Models}

Community wind ownership has been slow to develop in the UK, for a number of reasons. First, it is argued that the NFFO system of price support is administratively burdensome and therefore not well-suited for small wind projects (see Text Box 3). Second, the negative sentiment created by planning and permitting wars over large wind projects has in some cases spilled over to smaller projects as well. Third, unlike many of its European neighbors, the UK does not offer any tax incentives or capital investment subsidies for wind projects - the NFFO has been the sole source of support, and the number of projects able to receive NFFO support is by nature limited. Nonetheless, local developers, citizens, and even the British government (at least in principle) have shown great interest in community-owned wind projects, and there have been two successful participatory wind ownership projects to date.

The UK does not have a specific cooperative law, which means that it is possible to structure almost any legal form of business along cooperative principles (R. Mitchell 1994). While there 
are potentially as many as six legal structures suitable for participatory wind ownership in the UK, this case study will focus on the two that have been so far employed: the industrial and provident society (IPS) and the public limited company (plc).

\subsubsection{Industrial and Provident Society (IPS)}

\section{Background}

An industrial and provident society is a legal structure appropriate for organizations pursuing both economic as well as social goals, and may be registered either as a bona-fide cooperative society or as a society for the benefit of the community. Since the latter is most commonly associated with organizations conducting charity work, the following discussion will focus on the industrial and provident society registered as a bona-fide cooperative, which is more relevant to community-owned wind schemes. To date there has been only one industrial and provident society involved in the ownership of wind turbines in the UK, making it difficult to generalize about this model. As a result, much of the following discussion, as well as the text box case study, is based on the Baywind Energy Cooperative's ownership of two of the five turbines at Harlock Hill in Cumbria.

\section{Operations}

An industrial and provident society (IPS) must have at least seven members, and can issue a maximum of $£ 20,000$ worth of shares to each member. An IPS will generally be organized according to standard cooperative principles, such as open membership, one member one vote, and distribution of profits. Because an IPS is not technically by law a cooperative, however, there is considerable room for flexibility in operations. For example, it is possible to restrict membership to (or favor members from) certain geographic areas, and to require the purchase of a minimum number of shares. Perhaps more importantly, an IPS need not abide by the strict cooperative practice of basing dividends on the degree of patronage, but rather may pay dividends according to the level of investment (see Harlock Hill text box). This freedom facilitates fundraising, though the $£ 20,000$ investment limit placed on IPS members somewhat dilutes this benefit.

One advantage that an IPS has over other forms of ownership is the unrestricted ability to advertise shares to the public. The other legal business form that has been used in the UK for community-owned wind projects - the public limited company - can also offer shares to the general public, but must raise the target amount stated in its prospectus within 40 days, which is a tight deadline for mobilizing diverse community dollars.

\section{Financing}

Conditions in the U.K. during the 1990s have favored developer-led over community-led participatory wind projects, regardless of the ownership structure chosen (i.e., this is not specific to an IPS). First, a general lack of familiarity with wind power in the UK relative to other European countries such as Denmark made it extremely unlikely for a community group to undertake the task of developing a project on their own. Second, as mentioned above, the significant time commitment and complexity of bidding in an NFFO tender discouraged community involvement from the outset. Third, in order to maximize what limited economies of scale can be achieved within the small wind band, projects are often larger than would otherwise 
be undertaken by a community group; NFFO3's DNC limit of 1.6 MW allowed projects as large as $5.3 \mathrm{MW}$, assuming a 30\% capacity factor. Finally, the terms of the Non-Fossil Purchasing Agency (NFPA) contract awarded to successful NFFO bidders restricts sub-contracted relationships with third parties, more or less requiring the bidder to develop and operate the project. The NFPA wants assurances that the project will operate within a certain range of expectations, and understandably has little confidence in the ability of community groups to properly develop and manage a project, for the first reason listed above. All of these factors have worked together to discourage community-led participatory wind schemes and to favor a developer-led approach.

The primary practical implication of a developer-led approach in terms of financing is that the developer must still arrange for financing to construct the project. Because UK community groups, with their limited wind power experience, cannot reasonably be expected to raise enough capital to purchase a $5 \mathrm{MW}$ wind farm (for example) that has not yet been built, community investment typically occurs only after the project has been commissioned, and perhaps only in single turbine increments. In the U.K, therefore, community involvement in a project does not necessarily relieve the developer of the burden of financing the project (as it often does in Sweden and Denmark).

While community-owned wind projects do not directly benefit from the lower cost of financing seen in community-led projects in Denmark and Sweden, there are some indications that having a community willing to invest in a project can lower the cost of finance to a developer. In fact, The Wind Company (the developer of Harlock Hill) claims that not only did its financiers take comfort in the fact that the Baywind Cooperative share subscription was proceeding on schedule, but also Baywind members took comfort in The Wind Company's ability to raise development financing from commercial sources. In other words, the two concurrent processes fed on each other, with both investor classes being reassured by their counterpart's willingness to finance the project (Boxer and Harrop 1997).

While it is hard to generalize about typical share size given the existence of only one community-owned project involving an IPS, the Baywind Cooperative at Harlock Hill sold shares for $£ 1$ with a minimum investment of 300 shares. The cooperative offered a savings scheme that allowed members to accumulate their investment over the six-month period that shares were offered. The fact that only 35 out of approximately 650 initial members who purchased the first turbine took advantage of this offer indicates that a sum of $£ 300$ is within reach of most households' personal savings. In fact, the average investment in the Baywind Cooperative’s first turbine was $£ 1000$, above even the $£ 500$ minimum to qualify for EIS tax relief (see Taxation section).

At the other end of the spectrum, the upper limit on IPS investment of £20,000 per investor will generally not be a binding constraint on wind development, except maybe in the case of small or sparsely populated areas (e.g., small islands) where fewer potential investors may need to raise larger amounts of capital per person in order to finance a project. In such an instance another form of ownership may be more advantageous; for example, a private limited company is not subject to maximum investment limits, and its main drawback - the fact that it cannot legally 
advertise shares to the public - would probably not prohibit the word from spreading in such a micro environment (Boxer and Harrop 1997).

\section{Taxation}

An individual who invests in new eligible shares of a qualifying unquoted society may be eligible for tax relief under the provisions of the Enterprise Investment Scheme (EIS). Eligible shares are ordinary shares that carry no preferential rights, and must have been issued for the purpose of raising money for a qualifying business activity to be carried out in the UK. Providing these and other conditions are met, the EIS provides tax relief of $20 \%$ of invested amounts greater than or equal to $£ 500$ in the year the investment is made. For example, a qualifying investor purchasing $£ 500$ worth of shares in a qualifying society could claim a $£ 100$ income tax exemption in the year the investment was made, effectively reducing the investment amount to $£ 400$.

While EIS tax relief is not specific to renewable or wind energy, the Baywind Energy Cooperative took steps to ensure that its members would qualify for EIS relief if the members themselves were eligible. One necessary step was to prohibit the cooperative from redeeming shares for a period of five years from issuance. Members can sell their shares to other members or non-members during this period, but the cooperative itself cannot redeem them. After five years, Baywind will decide whether to alter its bylaws to allow share redemption.

Besides EIS tax relief on investment, the UK offers no other tax incentives to encourage community wind ownership. Dividends from the IPS are taxed as regular income.

\section{Liability}

All members of an IPS have liability that is limited to any unpaid amount on outstanding shares. Since most societies require all shares to be pre-paid, in essence each individual's liability is limited to the amount invested.

\section{Liquidity}

Shares in an IPS are usually redeemable by the society, and are usually issued and redeemed at par. Shares are also transferable to other members or those seeking membership. As mentioned above, however, rules governing EIS tax relief may prohibit an IPS from redeeming shares for some initial period, in which case an investor's only exit option is to transfer shares to another willing party. The Baywind Cooperative will facilitate such transfers by maintaining a register of interested buyers and sellers, and posting the audited value of a share each year at its annual meeting (potentially creating a good time to trade). 


\section{Text Box 4. The Baywind Energy Cooperative at Harlock Hill*}

In 1993, the Swedish wind developer Vindkompaniet AB (VKAB) formed The Wind Company (TWC) for the purpose of establishing the UK's first cooperatively owned wind project. VKAB and TWC selected the site at Harlock Hill in Cumbria for two main reasons: the farmer who owned the land was enthusiastic, and the South Lakeland District Council (SLDC) and the Cumbria County Council had already identified the Harlock Hill area as a "least constraint" area for wind development. With VKAB's technical assistance, TWC secured a contract from NFFO3's small wind band for seven $500 \mathrm{~kW}$ turbines at a price of 5.4 pence/kWh. In May 1995, despite its previous "least constraint" designation, SLDC permitted only 5 of the 7 turbines due to noise concerns.

During the site selection and planning stages, TWC had maintained contact with local people who were interested in the cooperative concept, and in November 1995, seven local people formed an industrial and provident society (IPS) known as the Baywind Energy Cooperative Limited. Because Harlock Hill was to be the UK's first community-owned wind project, TWC and the seven original members (six of whom became board members) felt that organizing as an IPS would give the cooperative the flexibility it needed to offer shares to the public over a period of time sufficient to raise the necessary amount of capital. The share offer was launched on April 26, 1996 (the $10^{\text {th }}$ anniversary of the Chernobyl nuclear explosion) with a goal of raising $£ 620,000$ by the end of October, enough to purchase one of the five turbines from TWC on a turnkey basis. To reduce administrative costs, the minimum investment per member was set at $£ 300$, and Baywind offered a savings scheme to help people accumulate this amount over a six-month period (only 35 of the 650 investors in the first turbine took advantage of this offer, implying that $£ 300$ is within reach of most household's personal savings). By October 11, with 650 members investing about $£ 1000$ on average, Baywind had raised enough capital to buy its first turbine, and extended the share offer to those wishing to purchase a second turbine.

While Baywind was conducting its share offer, TWC was also arranging financing to construct the 2.5 MW project. TWC chose to put up $20 \%$ of its own equity and finance the remaining $80 \%$ in debt from Triodos Bank, an ethical bank from the Netherlands with a long history in financing wind projects. Triodos was prepared to accept lump-sum repayments of the debt as Baywind purchased single turbines from TWC, but required the formation of a new company with a clean balance sheet - Harlock Hill Ltd. (HHL) - to develop the project.

Under the terms of the NFFO contract, HHL is required to operate and maintain all five turbines over the 15-year life of the contract. Furthermore, the project is to be metered as a whole, and not on an individual turbine basis. Thus, Baywind and HHL drew up an electricity supply agreement under which Baywind would be paid $20 \%$ of the total project revenue (for its first turbine). This agreement eliminates the potential for wrangling over which of the five turbines Baywind would purchase (i.e., micro-siting advantages), and also mitigates risk by giving both HHL and Baywind a strong incentive to see the entire project as a whole succeed.

Construction began in September 1996, and the project was commissioned in January 1997. Wind World, the turbine manufacturer and turnkey construction contractor, offered a 10-year warranty and production guarantee (at 90\% of expected output in a "normal" wind year) package; Baywind pays nothing for this package for the first five years, providing added security to members.

On October 25 of 1997, Baywind bought its second turbine at Harlock Hill, raising total investment to $£ 1,240,000$ from approximately 1,100 members. Assuming that they qualify for tax relief under the Enterprise Investment Scheme (EIS), members investing in 500 shares or more of either turbine can expect to earn an internal rate of return of about $9 \%$ after tax over 15 years. Without EIS relief, the 15-year IRR drops to about $7 \%$ after tax.

TWC has identified several factors that have been critical to the success of Baywind and Harlock Hill:

- The simple, democratic, and robust ownership structure enabled by an IPS

- The concurrent raising of finance by both Baywind and TWC, which reassured all involved parties as to the viability of the project

- Separating the development activities from the fundraising activities of the cooperative (i.e., the developer-led approach was seen as a success factor)

- Structuring the project to reduce risk to the cooperative. This was accomplished by isolating HHL's debt from the cooperative investment (so that any turbine purchased by the cooperative was debt-free), by Wind World's 10 -year warranty and production guarantee package, and by making Baywind investments $100 \%$ refundable in the event that the project failed.

*Much of the material in this text box is adapted from Boxer and Harrop (1997). 


\subsubsection{Public Limited Company (plc)}

\section{Background}

To date there is only one public limited company - The Wind Fund plc - involved in community wind ownership schemes in the UK. Much of the non-generic discussion concerning public limited companies that follows is based upon The Wind Fund's activities to date.

\section{Operations}

The Wind Fund plc is the UK's first direct investment fund for small renewable energy projects (particularly wind and hydro, which are the most commercially viable technologies). A public limited company is well structured to serve this purpose: there is no limit on the amount each member can invest, and the fund is able to offer shares to the public. Public limited companies are required by law to raise a minimum total share capital of $£ 50,000$, but this amount is low enough to not be restrictive, given the capital-intensive nature of wind and hydro. To raise capital, a plc must offer shares via a prospectus, and must raise the minimum amount of capital listed in the prospectus within forty days. Because of this time constraint, a plc is more likely to seek investors on a national rather than local basis, and this is the approach taken by The Wind Fund plc.

The Wind Fund is essentially a financier of small renewable energy projects, pooling its investors' capital to provide equity financing to small developers or companies set up specifically to develop a wind or hydro project (such as Harlock Hill Ltd.). Such projects are often badly in need of financing, yet are often overlooked by commercial financiers who do not consider it worth their while to dabble in projects below a certain size. The Wind Fund's objective is to fill this gap by providing equity finance to projects that are both environmentally responsible and supported by the local community. As the project generates revenue, The Wind Fund distributes that revenue to its shareholders in the form of dividends.

While its fundraising occurs on a national basis, The Wind Fund encourages local community involvement in its projects. For example, its first investment - in the $2.4 \mathrm{MW}$ Haverigg 2 wind cluster in Cumbria - was structured to allow community ownership, and in May 1999, 10 months after the project's commissioning, the local Baywind Energy Cooperative purchased one of the four $600 \mathrm{~kW}$ turbines. To date, The Wind Fund's only other investment is in a $1 \mathrm{MW}$ hydro project in Scotland.

\section{Financing}

As with an IPS, shares in a plc are generally sold at par for $£ 1$, with some minimum purchase threshold to reduce administrative burdens. The minimum investment in The Wind Fund's two share offerings to date has been between 250 and 300 shares. The first share offering took place in 1995, raising more than $£ 575,000$. Another $£ 311,000$ was placed privately in January 1998, and the second share offering was launched in May 1998, with a goal of raising at least $£ 2$ million. At the end of 1999, The Wind Fund's total assets came to £2,786,287. Of that total, only $£ 812,730$ was invested in the fund’s two projects, with the rest in bank deposits (The Wind Fund 2000). 
In some sense, The Wind Fund's approach addresses the main disadvantage facing developer-led community-owned schemes - the fact that developers must still seek traditional sources of financing in order to develop the project. ${ }^{18}$ With its nationwide pool of investors and quick access to capital, The Wind Fund can help small projects that will ultimately be owned by the local community to get through the development phase while local funds are being raised.

\section{Taxation}

Investments of over $£ 500$ may qualify for tax relief under the Enterprise Investment Scheme, depending upon the status of both the investor and the plc (see the industrial and provident society taxation section for more details on EIS tax relief). There are no other tax advantages afforded to investors in a public limited company.

\section{Liability}

Investors in a public limited company are liable only for their own shares; i.e., liability is limited to the total of paid-up and any unpaid shares. The Wind Fund plc requires shares to be fully paid-up in advance.

\section{Liquidity}

Public limited companies may be listed on a stock exchange, but most are not, and it is unlikely that a plc involved in community wind ownership would choose to be listed. As a result, investors wishing to exit must find others willing to purchase their shares. Triodos Bank, the parent company behind The Wind Fund, maintains a "matched bargain market" in which it seeks to match up interested sellers with prospective buyers, and also calculates the correct market value of a share at regular intervals.

\subsubsection{Looking Ahead}

Community wind ownership in the UK remains in a tenuous position. For all the criticisms of the NFFO process, the small wind bands of NFFO3-5 did provide at least some smaller projects with guaranteed fixed-price 15-year contracts. As the government abandons the NFFO in favor of a renewable portfolio standard, there is no indication that small projects will continue to receive even the minimal level of preferential treatment that they have enjoyed in the past. As a result, the long-term investment climate is quite uncertain, and The Wind Fund plc is finding it more difficult than it had anticipated to identify suitable new projects for investment (The Wind Fund plc 2000).

At the same time, however, there are shreds of hope for community wind ownership in the UK. Relative to some of its European neighbors, the UK has never had particularly favorable policies towards community-owned wind, and so in this respect, there is little to be lost. The two major community efforts to date - the Baywind Cooperative and The Wind Fund plc - have broken new ground and proven that community wind ownership can succeed in the UK, establishing models for others to follow. There are also signs of new models emerging involving green pricing (Massy 1999), and still others will no doubt be developed under the new renewable portfolio standard. Finally, given the strength of the UK wind resource, the small amount of

\footnotetext{
${ }^{18}$ This problem is discussed in more detail in the financing section of industrial and provident societies.
} 
wind capacity installed to date, and the growing need to develop the resource more fully in the future, it is perhaps likely that the political situation towards wind power will only improve. And with public opposition to large-scale wind farms still strong, smaller community-owned projects may stand to benefit the most. 


\section{SUMMARY OF EUROPEAN EXPERIENCE}

This chapter draws together the highlights of the European case studies and examines the aggregate lessons from European experience with community wind ownership. It begins by grouping each of the community ownership models into three broad categories in an attempt to abstract from the details and facilitate a more sweeping discussion. It then examines the aggregate impact of community wind ownership in Europe, and attempts to identify and understand the factors that have driven Europe to pursue this form of wind development. In preparation for shifting the focus to the United States, the chapter ends with a discussion of the inherent benefits of community wind ownership, i.e., those benefits that are specific to the ownership medium itself, and independent from the underlying policies supporting community wind ownership. These inherent benefits - and not policy support - are likely to drive community ownership in the United States.

\subsection{Categorization of European Models}

The preceding European case studies detailed a total of seven models for community wind ownership - one in Denmark, three in Sweden, one in Germany, and two in the UK. While broad similarities exist between some of these models, there are also many specific differences driven by characteristics particular to each country. For example, the real estate commune is a business structure somewhat unique to Sweden, and is therefore not particularly applicable to other countries. Denmark's wind partnerships operate in a similar manner to Swedish wind cooperatives, but are not bound by strict cooperative principles limiting investment to consumption, due largely to nuances in Danish electricity law that prohibit cooperatives from owning wind turbines. While these specific differences are noteworthy, and highlight both the limits to generic cross-country replication and the need to identify business and legal structures that work within each country's given system, it is perhaps more useful to consolidate these seven models into a few general categories in order to facilitate discussion of their impacts in Europe and their applicability to the United States. This section identifies and discusses three broad categories: community-led models, developer-led models, and investment funds. Table 6 summarizes the main distinctions between categories. 
Table 6. Categorization of European Community Wind Ownership Models

\begin{tabular}{|c|c|c|}
\hline Community-Led & Developer-Led & Investment Funds \\
\hline $\begin{array}{l}\text { Denmark } \\
\text { General Partnerships } \\
\text { Sweden } \\
\text { Real Estate Commune } \\
\text { Consumer Cooperative } \\
\quad \text { (traditional/local) }\end{array}$ & $\begin{array}{l}\text { Germany } \\
\text { Limited Partnerships } \\
\text { UK } \\
\text { Baywind Cooperative } \\
\text { Sweden } \\
\text { Consumer Cooperative } \\
\text { (national) } \\
\text { Denmark } \\
\text { Middelgrunden }\end{array}$ & $\begin{array}{l}\text { UK } \\
\text { The Wind Fund plc } \\
\text { Netherlands } \\
\text { "Green" Funds }\end{array}$ \\
\hline \multicolumn{2}{|c|}{ Specific Projects } & No Specific Project \\
\hline
\end{tabular}

\subsubsection{Community-Led}

Community-led models are those under which projects are initiated, developed, and operated primarily by the local community, or "community of locality" (as discussed in chapter 2). This category, which includes Denmark's wind partnerships and Sweden's real estate communes and traditional consumer cooperatives, encompasses perhaps the purest forms of community wind ownership, often involving significant grass-roots efforts and participant sweat equity. Sweden's Glimminge Real Estate Commune (see Text Box 2), in which two local farmers approached a turbine manufacturer, organized the commune, and - with the manufacturer's assistance installed and now maintain a $500 \mathrm{~kW}$ turbine, provides a good example of a community-led project. Many other community-owned wind projects in Sweden and Denmark, and a smaller number of projects in other countries, have evolved in a similar manner.

As the "original" form of community ownership, the community-led approach has no doubt been an important element in getting the wind industry and the market for wind power off the ground. Some of the same factors that have contributed to its success, however - including geographic ownership restrictions and tax advantages that are tied to the level of consumption - now threaten to limit the scalability of this approach. The potential pool of investors not already fully invested in a local wind project is growing increasingly smaller in both Denmark and Sweden, a fact that has been acknowledged by the Danish government as they have gradually eliminated geographic ownership restrictions. In Sweden, the market, rather than the government, has responded to the saturation of the local investor pool: Sveriges Vindkraftkooperativ has teamed up with Falkenberg Energi to sign up new cooperative members nationwide.

These developments signal the beginnings of a paradigm shift. Pooling capital from across the nation (or, in the case of Denmark, from across Europe) will be more transaction-cost-intensive than pooling capital from within the local community, and in many cases will be beyond the means (or will) of a local community group. Similarly, the larger projects that are likely to result from diverse new capital inflows may require a degree of wind development and maintenance expertise that is beyond the capabilities of the average investor. The growing trend towards large 
offshore developments, as well as the sophistication that will be required to negotiate the tradable green certificate market as both Denmark and Sweden implement renewable portfolio standards, are yet two more examples of how wind energy in these two countries is beginning to move beyond the local level.

These developments - most or all of which are important steps forward for wind energy in general - need not be the death of community-owned wind projects. Instead, they merely signal the need to move on to a different model of community ownership - one in which a third party minimizes transaction costs by handling many of the details. This so-called developer-led approach will be discussed next.

\subsubsection{Developer-Led}

Developer-led models are those under which wind projects are initiated, developed, and perhaps operated by developers, with the community playing only a passive investment role. This broadest of categories, which includes Germany's limited partnerships, the UK’s Baywind Energy Cooperative, Sweden’s Sveriges Vindkraftkooperativ/Falkenberg Energi national cooperative model, and Denmark's Middelgrunden project, may involve only the community of locality, but more often will look to the larger community of interest as well for equity financing.

In Germany, the absence of any geographic ownership restrictions or limits on investment size has encouraged the development of larger projects than are typically seen in Denmark or Sweden, and has been a driving factor behind Germany's adoption of the developer-led approach. The UK has favored the developer-led approach for different reasons, including a relative lack of familiarity with wind power in general (and no turbine manufacturing base to speak of), as well as the relatively high transaction costs of securing an NFFO contract. The latest Danish and Swedish projects are included in the developer-led category for reasons discussed in the previous section.

Community investment in a developer-led project can occur either pre- or post-development. In Germany, where familiarity and comfort with investments in wind projects are relatively high, due both to the stability of an attractive feed-in tariff as well as readily available low-cost debt financing from the DtA, community investors often fund projects prior to development (ECOTEC 1999). This is also the case in Denmark. In the UK, on the other hand, there have been only two community-owned wind projects to date, and both were purchased from the developer on a turn-key basis once operational.

While post-development investment reduces the community investors' risk, it also forces the developer to arrange development financing, which will almost certainly increase the project's cost, and may even be impossible to secure over the range of smaller projects that are typically community-owned. The final category of community wind ownership models - investment funds - exist in part to fill this need for financing among smaller projects that are often below the minimum size threshold of commercial financiers. 


\subsubsection{Investment Funds}

The final category of community wind ownership models includes investment funds, where a fund manager pools investment capital from the "community of interest" and then invests that capital in developer-led projects. The distinction between the investment fund and developer-led approaches is subtle but important: the developer-led approach raises a defined amount of capital for a specific project, whereas the investment fund approach simply amasses an unspecified amount of capital from those individuals interested in investing in wind or renewable energy in general, and then searches for suitable projects in which to invest. While community investment in a developer-led project may occur either pre- or post-development, an investment fund typically invests either prior to or during development, taking an equity stake in a company specially created to develop the project. In this way, investment funds provide financing from the community when it is most needed - while the project is being built. Later, once the project is operational, the investment fund may choose to sell part (or all) of the project to a local community group, as happened in the UK when The Wind Fund plc sold one of its four $600 \mathrm{~kW}$ turbines at Haverigg II to the Baywind Energy Cooperative.

Besides The Wind Fund plc, other notable investment funds include the tax-advantaged "green funds" offered by a handful of banks in the Netherlands. Individuals investing in green funds are not taxed on the interest earned, allowing banks to offer a lower rate of return to investors, and likewise loan the funds out a low rate, usually about $1.5 \%$ below market. As a form of debt financing, green funds are different from the equity ownership structures that are the focus of this paper, but nevertheless merit attention as a potentially important source of low-cost financing for renewables. ${ }^{19}$

\subsection{Aggregate Impact of Community Wind Power Ownership in Europe}

More than half of the combined wind capacity in Germany, Denmark, Sweden, and the UK is community-owned. Moreover, as these four countries host about half of the world's wind development, community ownership within these four countries accounts for about $28 \%$ of worldwide wind capacity. Table 7 provides an approximate breakdown of community ownership by country, in terms of capacity and also the number of household investors. ${ }^{20}$

\footnotetext{
${ }^{19}$ Green funds are not specifically aimed at renewable energy projects, but rather projects with a positive environmental profile in general. Most renewable energy projects do, however, qualify for green funds investment.

${ }^{20}$ The aggregate number of household investors in these four countries is not very different from the number of households served by either a regulated or competitive green power product in the United States. Prior to the California electricity crisis, roughly 360,000 households, or about $1 \%$ of all American households with access to a regulated or competitive green power product, were being served by green power (Wiser, Bolinger, and Holt 2000). The amount of new renewable generating capacity supporting these products equaled about 50 average MW, or 200 MW of wind power assuming a $25 \%$ capacity factor and that all of the capacity is wind power. In Europe, a similar number of households have been responsible for the installation of over 5,000 MW of new wind capacity. While these two approaches are not really comparable given the different time frames and capital outlays involved in each, Europe's experience is nevertheless illustrative of the power of the individual to finance wind development, if given opportunities and incentives.
} 
Table 7. Community-Owned Wind Development in Europe (2000)

\begin{tabular}{|l|c|c|c|c|}
\hline & $\begin{array}{c}\text { Total Wind } \\
\text { Capacity } \\
\text { (MW) }\end{array}$ & $\begin{array}{c}\text { Community-Owned } \\
\text { Wind Capacity* } \\
\text { (MW) }\end{array}$ & $\begin{array}{c}\text { Community-Owned } \\
\text { Share of Total } \\
\text { Capacity }\end{array}$ & $\begin{array}{c}\text { Number of } \\
\text { Wind Turbine } \\
\text { Owners** }\end{array}$ \\
\hline Germany & 6,161 & 4,621 & $75 \%$ & 100,000 \\
\hline Denmark & 2,268 & 284 & $13 \%$ & 175,000 \\
\hline The UK & 414 & 3 & $1 \%$ & 1,802 \\
\hline Sweden & 240 & 30 & $13 \%$ & 15,000 \\
\hline Total & $\mathbf{9 , 0 8 3}$ & $\mathbf{4 , 9 3 8}$ & $\mathbf{5 4 \%}$ & $\mathbf{2 9 1 , 8 0 2}$ \\
\hline
\end{tabular}

*Only joint forms of ownership are represented in the capacity numbers.

**The number of wind turbine owners may include households that individually own turbines.

The capacity numbers in the table represent only joint forms of ownership: limited partnerships (GmbH \& Co. KG) and partnerships of sole proprietors (GbR) in Germany, general partnerships in Denmark, cooperatives and real estate communes in Sweden, and cooperatives or investment funds in the UK. Expanding the definition of "community ownership" to include individually owned turbines would boost the total by at least 2400 MW (approximately 1600 MW in Denmark and $800 \mathrm{MW}$ in Germany), raising the share of community-owned development in these countries to about $80 \%$, and in the world to over $40 \%$. These sizable numbers demonstrate that, despite the quaintness implied by its name, community-owned wind energy is not a niche market, but rather a mainstream form of wind development.

Of the three categories of community ownership models identified in the previous section, the developer-led approach, which includes not only Germany, but also Denmark’s large Middelgrunden project and Sweden's national cooperative model, has installed the majority of capacity among community-owned projects. This finding is intuitive, in that developers have the wherewithal to complete larger projects than a typical community group would warrant, potentially in a more timely fashion. The community-led approach, dominant in Denmark and Sweden, ranks second in amount of capacity installed (with notably more capacity than shown in the table if individually-owned turbines are included), while the investment fund approach ranks a distant third, with just a few megawatts installed in the UK.

The poor performance of the investment fund approach relative to the other two model categories is not necessarily a sign of inferiority, but rather a testament to the importance of policy in creating an environment conducive to community ownership in general. In fact, the UK, which despite considerable efforts has achieved only limited success with community ownership to date, serves as an instructive "control" subject against which the drivers of community ownership in Germany, Denmark, and Sweden can be isolated.

\subsection{Factors Enabling Community Ownership}

A comparison of underlying policies and institutions supporting wind power development in Germany, Denmark, and Sweden to those in the UK reveals five primary factors that are absent in the UK but have contributed to the success of community wind power ownership in the other 
three countries: feed-in tariffs, tax advantages, standard interconnection agreements, a domestic wind turbine manufacturing base, and familiarity with cooperative forms of ownership.

\subsubsection{Feed-In Laws}

Germany, Denmark, and to a lesser extent, Sweden, all offer or have offered attractive feed-in tariffs for wind power. These tariffs, historically set at $90 \%$ of the average nationwide retail rate for all customer classes in Germany and $85 \%$ of the local retail rate for small consumers in Denmark, have created a stable, profitable, and essentially unlimited market for wind power, and one that can be accessed with very low transactions costs.

The UK, on the other hand, has offered limited and intermittent support to wind power through five NFFO orders (three of which have had a separate small wind band) in eight years. The understandably intense competition for these limited funds increased the transactions costs of compiling a bid, and at the same time decreased the likelihood of being awarded a contract. Small community-owned projects have found it hard to compete in this environment.

\subsubsection{Tax Advantages}

With the exception of those in the UK, most European community-owned wind ventures have enjoyed favorable tax status. Tax advantages generally come in three forms: tax-free generation, refund of energy and/or $\mathrm{CO}_{2}$ taxes, and favorable depreciation rules for businesses. Tax-free generation is found primarily in Sweden and Denmark, where each member of a cooperative, commune, or partnership is not taxed on his or her share of the income from the turbine's production as long as the income (or the amount of electricity produced) does not exceed that member's annual expenditure on (or consumption of) electricity. ${ }^{21}$ Likewise, Sweden and Denmark are the only countries studied that refund some portion of electricity and/or $\mathrm{CO}_{2}$ taxes, though in 2001 the UK enacted a climate change levy, from which renewable generation is exempt.

Favorable depreciation rules for wind plant capital are found in all countries studied, with the exception of the UK. Both Sweden and Denmark allow businesses to depreciate the value of a wind turbine by up to $30 \%$ each year using the declining balance method, and to use the depreciation expense to offset other forms of business income (instead of, or in addition to, income from the wind turbine) (Helby 1998c, 1998f). This is one of the principal reasons many individual Swedish and Danish farmers have installed one or more wind turbines on their property as part of their farming business - to defer taxation on their other farming profits.

Better yet, limited partners (i.e., individual investors) in German wind partnerships have been able to write off fairly aggressive depreciation expenses (over 10 years until July 1997, when extended to 12 years) against all forms of income, including wage income. A recent redesign of German tax laws, however, has largely eliminated this tax shelter by requiring that depreciation

\footnotetext{
${ }^{21}$ The tax-free threshold is a bit arbitrary in Denmark, and has changed over time from 135\% to $150 \%$ of annual expenditures on electricity, and now to the current 3000 DKK. In Sweden, where community-owned projects generally adhere to strict cooperative principles, tax-free thresholds equal the annual amount of electricity consumption, rather than expenditure.
} 
of an investment be offset against income from that same investment or similar investments, rather than all income (Knight 2000, Langniss 2001). In concert with this change, the government has also threatened to extend the depreciation period beyond 12 years (Knight 2000).

The Netherlands offers the ultimate depreciation schedule - under the VAMIL scheme, up to $100 \%$ of eligible environmental investments (including wind turbines) can be written off in any year the owner chooses. This explains the high proportion of individual farmers, as opposed to cooperatives, that own wind turbines in the Netherlands.

\subsubsection{Standard Interconnection Agreements}

In concert with the feed-in tariffs offered by Germany, Denmark, and Sweden, distribution utilities in these countries (and others in Europe, though notably not the UK) are required to interconnect small wind projects to the grid according to a pre-determined set of rules defining technical requirements and division of financial responsibility. In Germany, Denmark, and Sweden, the generator must pay the cost of connecting to the nearest feasible point on the grid, while the distribution utility must pay the costs of strengthening or upgrading the grid as necessary to interconnect the generator. In Germany and Denmark, the utility can recover these costs through a surcharge on rates.

Requiring interconnection ensures a community-owned project of access to a market (most often the utility itself, through a feed-in tariff), while pre-defining interconnection requirements and responsibilities (both technical and financial) enables a community-owned project to accurately estimate the cost of interconnection in advance. Both of these factors reduce the project owners' risk.

\subsubsection{Wind Turbine Manufacturing Base}

Denmark’s world-class wind turbine manufacturing industry has played an important role in community wind development in both Denmark and Sweden. Representatives or sales agents from turbine manufacturers have often been the initial instigators of wind partnerships, cooperatives, or communes, providing resource assessment, financial projections, general guidance, and development assistance (Helby 1998d). This beneficial relationship is less evident in Germany, where developers, rather than sales representatives, have taken on most of these functions. Nevertheless, the very existence of a domestic wind turbine manufacturing industry in Germany and Denmark has no doubt influenced politicians in those countries to favor policies that are friendly towards domestic ownership. The UK, with no domestic turbine manufacturing industry to speak of, has lacked this potentially strong lobbying force.

\subsubsection{Familiarity with Cooperative Ownership Structures}

Many cooperative businesses today are organized according to the Rochdale principles of cooperation, first established in 1844 by one of the most successful early cooperative businesses, 
the Rochdale Society of Equitable Pioneers in Rochdale, England. ${ }^{22}$ Despite this auspicious and pioneering effort, however, the use of cooperatives has not permeated UK society to the degree that it has in other European countries such as Denmark and Sweden (Centre for Sustainable Energy 1997). Inspired by the Danish “Folk” movement of the mid-19 ${ }^{\text {th }}$ century, which aroused a national consciousness promoting the ideals of self-sufficiency and working together to improve people's lives, Danish agricultural cooperatives spread rapidly to almost every village following the formation of the world's first dairy cooperative in Denmark in 1882, creating one of the greatest commercial revolutions in the history of Denmark (Tranæs 2001). Likewise, Sweden has a long history of joint ownership of public goods, such as playgrounds, roads, parking lots, and sewage systems. In contrast, cooperatives in the UK have rarely moved beyond their agricultural base, meaning that the UK public in general is less familiar with this legal structure. For example, the organizers of the Baywind Energy Cooperative felt it necessary to undertake a strong educational campaign to familiarize the public about the benefits of cooperative ownership (Centre for Sustainable Energy 1997).

\subsection{Inherent Benefits of Community Ownership}

The foregoing discussion reveals that it is not community ownership per se, or the specific structure of the ownership model employed, that is responsible for Europe's strong wind growth (after all, seven different models of community ownership using three different primary approaches have all had at least some success), but rather the underlying institutions and supportive policies that have allowed individual investors to earn an acceptable rate of return from investing in wind energy. This does not, however, mean that community ownership is devoid of any inherent value on its own. Several of the benefits of community-owned wind power identified in Chapter II are exemplified in Europe:

- Increased public acceptance: One need look only as far as the UK to discover perhaps the greatest value of community wind ownership - increased public acceptance. The UK lacks all five of the drivers of community wind ownership identified in the previous section, yet has nonetheless made a concerted push towards community ownership in reaction to a string of planning denials and intense public opposition to the siting of larger commercial wind projects. By allowing the public to reap wind power's economic benefits, the UK - home to Europe's best wind resource - hopes to bolster public acceptance of and support for wind energy to levels seen in Denmark, Germany, and Sweden.

- Realized distributed generation benefits: Figure 7 (from Andersen 1998) shows the location of more than 5000 wind turbines in Denmark. With the exception of a noticeably heavier concentration along Denmark's windy northwest coast, the distribution of turbines throughout the country is remarkably consistent. This high degree of geographic dispersion not only reduces transmission losses, but also helps to reduce the potential severity of fluctuations in power output to the grid at any given

\footnotetext{
22 The Rochdale cooperative principles include open membership, democratic control (one member, one vote), distribution of surpluses in proportion to the level of patronage, and limited interest on capital.
} 
moment (as compared to what might occur if all wind development were concentrated in one area). Such geographic diversification enables greater levels of grid penetration, which Denmark will need in order to reach its official policy goal of obtaining $50 \%$ of its nationwide electricity consumption from wind power by 2030.

- Enhanced turbine manufacturing environment: While the presence of a strong wind turbine manufacturing industry was earlier identified as a driver of community wind ownership, a strong tradition of community wind ownership may also have contributed to the rise of Denmark's world dominance in wind turbine manufacturing. For many years, wind development in Denmark occurred in "onesies" and "twosies" - a few turbines at a time. This gradual and steady development enabled the Danish wind turbine manufacturing industry to learn from experience what worked and what did not, and allowed it to correct any problems as they arose. This pattern is in sharp contrast to wind development in the United States, where fast and feverish development spurts led to orders for thousands of turbines at a time, resulting in rushed engineering and mass production of flawed turbine designs (Berger 1997).

\section{Figure 7. Danish Wind Turbine Sites}

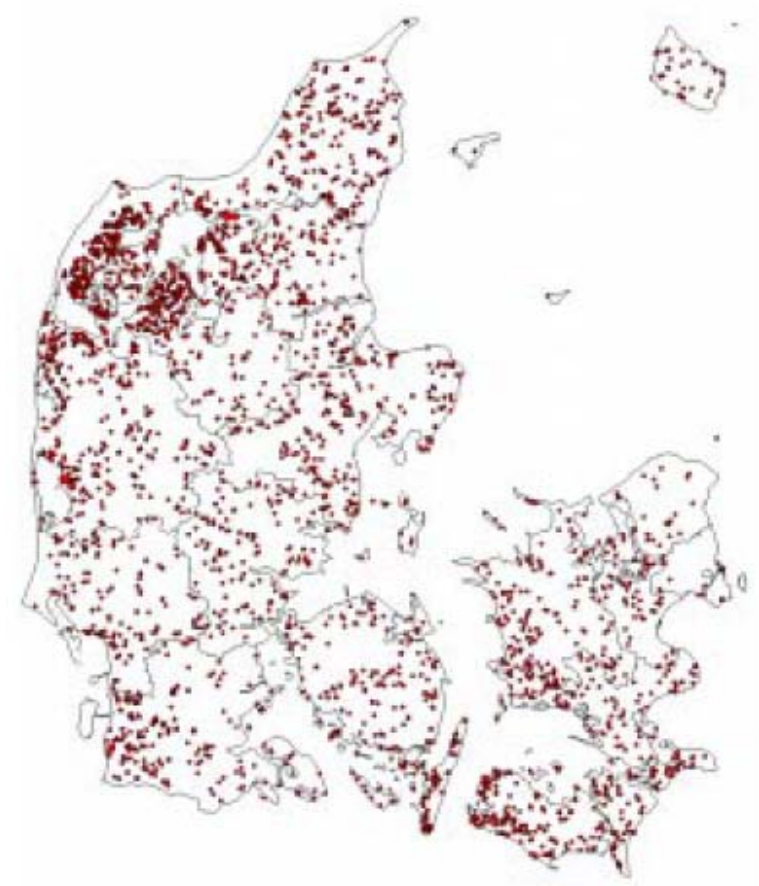

Figure 3. Siting of the more than 5200 wind turbines in Denmark. Source Energi \& Miljø Data.

- New and cheaper source of capital: Commercial financiers have up until recently been shut out of the European wind market by the availability of cheaper equity capital from individuals, as well as low-cost debt financing from various sources. The fact that commercial financiers have not been able to compete implies that community ownership has indeed lowered financing costs for European wind projects.

Thus, community ownership appears to have benefited the development of wind energy in Europe beyond merely serving as a vehicle through which public policies are implemented. Specifically, community ownership has increased public acceptance of wind power, realized distributed generation benefits, improved the manufacturing environment, and provided a large and relatively cheap source of capital to finance wind development. The next chapter turns to the United States to see which, if any, of these benefits could potentially be realized by community-owned projects. 


\section{Applicability to The United States}

The previous chapter showed that while community wind ownership has had a large impact in Europe, and that some of that positive impact is due to the inherent benefits of the community ownership model, for the most part, success must be attributed to underlying policies and institutions that favor community ownership in Europe. This chapter explores the prospects for obtaining some of the inherent benefits of community ownership in a less favorable policy environment. The chapter begins by examining a number of potential barriers to different categories of community ownership in the United States. It then ranks each category based on the relative number of barriers to implementation, and determines the most likely model for the US. Finally, it discusses potential applications of that model, drawing upon various contemporary efforts to foster community wind outside of Europe.

This chapter is meant to apply to the United States as a whole, and is therefore rather general in scope. The author acknowledges and the reader should be aware, however, that the United States is a large and diverse country, where state-specific characteristics - including law, energy policy, economic base, and culture - may play a more significant role than any broader national characteristics in determining the success of community wind ownership in a particular area. For example, Minnesota's favorable policies towards community wind development, ${ }^{23}$ in combination with a strong wind resource and an agricultural community perhaps more familiar than most with the intricacies of cooperative ownership, may dictate a different model of community wind development in that state than this paper recommends for the broader US. The intention of this paper, and this chapter in particular, is not to provide an exhaustive examination of barriers and opportunities to community wind ownership in individual states - that analysis is left to others, or subsequent projects. Instead, the author's intent is to present a broad overview to barriers and opportunities on a national level, perhaps highlighting state-specific information where relevant, but not systematically reporting it.

\subsection{Barriers to Community Wind Ownership in the United States}

Potential barriers to community wind ownership in the US come in seven broad categories: legal, regulatory, tax, market, consumer/investor, technical, and cultural.

\subsubsection{Legal Barriers}

With the exception of the real estate commune used in Sweden, all other legal structures employed in Europe to enable community-owned wind projects are also present in the United States. Furthermore, the US has recently instituted a new form of business known as a limited liability company (LLC), which combines the most attractive features of a partnership and a corporation: the single-tax treatment of a partnership, and the limited personal liability of a

\footnotetext{
${ }^{23}$ Minnesota provides a $1.5 \$ / \mathrm{kWh}$ production incentive to wind projects less than $2 \mathrm{MW}$ sited on agricultural land. Minnesota has also defined the wind as an agricultural commodity, allowing farmers to take advantage of lowinterest agricultural loans when developing wind projects, and offers property tax exemptions and planning and permitting exemptions for small projects.
} 
corporation. Some have suggested that an LLC could be a more suitable structure than a cooperative for a community-led wind project (Schoenrich and Nadeau 1997).

In the context of a community-owned wind project, however, in which diverse investors own a part of the LLC (or other business form), one must also consider the effects of securities law. In general, if the LLC involves passive investors, as a community-owned wind project presumably would, then the LLC becomes subject to Securities and Exchange Commission (SEC) regulations, which could greatly amplify legal complexity and expense. In addition to SEC regulations, such businesses also need to comply with state securities laws.

Fortunately, there are some exemptions from SEC oversight. SEC rules exempt an "intrastate offering" - the sale of shares within the state in which the LLC is registered to investors residing in that same state - from securities law (Nolo 2001, SEC 1999). Given that electricity restructuring has been occurring on a state-by-state basis, and retail electricity markets have therefore typically followed state boundaries, qualifying for this exemption should not be difficult. There are also exemptions for "private offerings" (the unadvertised sale of shares to competent investors) and for small businesses issuing less than \$5 million in any 12-month period (SEC 1999). Many states have similar exemptions.

Thus, while certain legal structures will no doubt present more obstacles than others (e.g. the investment fund approach will most likely not qualify for an SEC exemption), with careful planning, legal issues do not seem to present an insurmountable hurdle to community wind ownership in the US.

\subsubsection{Regulatory Barriers}

Perhaps the single largest regulatory barrier to community-owned wind projects in the United States is the lack of uniform interconnection standards. Unlike in Europe, the responsibilities of utilities and generators with respect to interconnection have not been clearly defined in the US, and as a result, the cost (or even feasibility) of interconnection to the grid often becomes a significant barrier to smaller projects (See Alderfer, Eldridge, and Starrs 2000 for a discussion of interconnection barriers in the United States).

Stringent licensing requirements could also pose a barrier to community ownership, if for example, a small cooperative selling power only to its members were required to be licensed as an energy service provider. Similarly, the licensing of generation facilities could be particularly onerous for a small community group (Poch 1999).

\subsubsection{Tax Barriers}

The United States tax code encourages wind ownership by big businesses, not personal investors (or even small businesses). Unlike in Europe, no form of wind ownership, except for netmetered applications, generates revenue that is free from personal income tax. Likewise, since energy use and $\mathrm{CO}_{2}$ emissions are not taxed in the US, there are no opportunities to stimulate wind power by these means. Businesses, however, can effectively eliminate their tax liability for the first five years by depreciating turbines through the 5-year modified accelerated cost recovery system (MACRS), which is more favorable than the Swedish and Danish schedules 
starting in the third year, but less favorable than the Dutch VAMIL scheme. Furthermore, the federal production tax credit (PTC), which currently stands at $1.7 \$ / \mathrm{kWh}$ adjusted for inflation, encourages ownership by businesses with large enough tax liabilities to absorb the attractive combination of MACRS and the PTC. ${ }^{24}$ Such businesses are not likely to be those involved with community-owned wind projects.

In fact, businesses that are perhaps most likely to be interested in community wind ownership non-profits and cooperatives - may not be able to benefit from MACRS or the PTC at all, given that they generally have no tax liabilities. While there is no cash-equivalent version of MACRS to encourage wind ownership among these entities, there is a federal renewable energy production incentive (REPI) whose value mirrors that of the PTC (i.e., rising at the rate of inflation from $1.5 \$ / \mathrm{kWh}$ in 1993 to $1.7 \$ / \mathrm{kWh}$ in 2000 , and paid for the first ten years of a plant's operation). The REPI, however, is generally not as attractive as the PTC: the REPI involves an outlay of cash, making the availability of funds subject to annual congressional appropriations that cannot be depended upon. ${ }^{25}$ Once a plant qualifies for the PTC, on the other hand, it is guaranteed to receive the tax credit for ten years. ${ }^{26}$ Thus, while tax-free status for municipal utilities, non-profits, and cooperatives is a subsidy in and of itself, there are fewer incentives specifically targeting wind ownership among such entities than there are for taxable businesses.

\subsubsection{Market Barriers}

In Europe, most community-owned wind projects simply sell their output to the utility under an attractive feed-in tariff or NFFO contract. In the United States, utilities are required under the Public Utilities Regulatory Policy Act (PURPA) to purchase power from wind generators and other qualifying facilities (QFs), but only at the utilities' avoided costs. While in the past some states - most notably California with its Interim Standard Offer 4 contracts - interpreted avoided costs very liberally and offered attractive long-term contracts, today most contracts offered to QFs are uneconomic. Without a guaranteed profitable market, a community-owned wind project becomes significantly more risky.

In some cases, community-owned projects may find it difficult or impossible to reach a prospective market. Schoenrich and Nadeau (1997) describe a feasibility study to develop a community-owned project organized along consumer cooperative principles in Minnesota, where, as part of a deal involving nuclear waste storage, the state legislature required Northern States Power (NSP) to install (or purchase the output from) 425 MW of new wind capacity. Despite the existence of such a significant and proximate market for wind power, the study found

\footnotetext{
${ }^{24}$ This explains why the pattern of wind development in the US usually involves a developer selling the project to a larger corporation - as a sole purpose business, the developer does not have sufficient tax liabilities to reap the combined benefits of MACRS and the PTC.

${ }^{25}$ To date, all wind projects - which are given high priority as Tier 1 projects - that have applied for the REPI have been paid in full. Tier 2 projects, which include landfill gas plants, have received only partial REPI payments for the last four years, due to insufficient funding.

${ }^{26}$ While providing more investor security than the REPI, the PTC is also subject to politics, as the period in which it is available to new facilities must periodically be extended by congress (there is currently a bill before congress to extend the PTC beyond its scheduled December 31, 2001 expiration date). Once a plant has registered for the PTC, however, it can take advantage of the tax credit for ten years, regardless of whether the availability of the PTC for new plants lapses during that time period.
} 
that a cooperative structure would most likely be unable to access the NSP demand, since most farmers (the prospective cooperative members) buy their power from rural electric cooperatives, and not NSP. ${ }^{27}$

Rural electric cooperatives (RECs) may themselves present market barriers to community wind ownership. There are two types of RECs: generation and transmission (G\&T) cooperatives, and distribution cooperatives that serve retail customers and generally buy their power from G\&T cooperatives. Many distribution cooperatives have signed long-term power purchase agreements (i.e., "full requirements" contracts) that effectively prohibit them from producing their own power (Princeton Economic Research 1998; Alderfer, Eldridge, and Starrs 2000), thus limiting the ability of their members to interconnect a community-owned wind turbine. RECs have also in some cases been hesitant to pursue their own wind power projects at the risk of calling attention to their other generation, which in the Midwest is mostly coal-fired (Tennis, Jefferiss, and Clemmer 1998). Since distribution RECs "control the lines" to much of the customer base in the rural US, their support for wind power, and community-owned wind in particular, may be a prerequisite to success in some areas.

Finally, there has been much discourse on the fact that electricity markets and policies do not value the benefits of distributed generation (Princeton Economic Research 1998, Moskowitz et al 2000). While this is also generally true in Europe, where policies target the installation of renewable energy without regard to its effects on the transmission and distribution grid, one could argue that in Europe the value of such benefits are bundled into high feed-in tariffs. In the United States, where policies and markets tend to be leaner than in Europe, proper valuation of distributed generation's benefits takes on increased importance as a revenue source.

\subsubsection{Consumer/Investor Barriers}

In the United States, most of the attention paid to community-owned wind has focused on the Midwest, where the wind resource is generally appealing, at least one state (Minnesota) offers financial incentives encouraging small community wind ownership, and the local agricultural community has experience with cooperative ventures. While studies have shown strong interest in wind power among Midwestern farmers (Kemp, Schoenrich, and Lanphere 1995), several barriers to community ownership have emerged (Schoenrich and Nadeau 1997):

- Lack of a model: Since there has never been a community-owned wind project in the United States, farmers are understandably unfamiliar with wind power, and even less comfortable with the risks involved.

- Uncertain returns: A farmer's tax liability can vary greatly depending on how good of a crop year it is. Thus, there could be years when farmers that invest in wind turbines may not be able to benefit from the federal production tax credit (PTC) and favorable depreciation rules (MACRS). Since these two tax-related incentives often comprise the

\footnotetext{
${ }^{27}$ Recall from the Swedish case study that consumer cooperatives are based upon patronage, which in the case of a wind cooperative means that the cooperative members must also be customers of the utility to which the wind power is sold.
} 
bulk of a project's return on investment, ${ }^{28}$ projected returns to farmers are highly uncertain.

- Difficulty raising local equity: Farmers have limited investment dollars, and many projects competing for those dollars. As an unfamiliar and potentially risky investment with uncertain returns, wind power does not immediately emerge as a clear winner, and farmers have tended instead to lease or sell their wind rights to developers.

- Wind easements already sold: In many cases, farmers in the most promising sites along the Buffalo Ridge in Minnesota have already sold wind easements to Northern States Power (Schoenrich and Nadeau 1997). In order to develop a community-owned wind project, these farmers would need to negotiate with NSP to buy back their wind rights.

In addition to these somewhat Midwest-specific barriers, one of the largest consumer/investor barriers to community ownership of wind projects is liquidity. A community ownership model that links investment returns to electricity consumption must necessarily provide more liquidity than one that does not in order to attract the same level of investment: someone moving across country, or even to the next state, will not be willing to forfeit returns simply because he is no longer eligible to purchase electricity from a certain provider. Ownership models that are structured as an investment and are not tied to electricity consumption, such as Germany's developer-led approach, will not face this specific problem, as investor mobility will not reduce the attractiveness of the investment. Liquidity concerns, however, may still pose a barrier, as investments in renewable energy are most profitable as long-term investments, which may seem too risky or blasé to investors caught up in “day trading” mania.

\subsubsection{Technical Barriers}

In contrast to Europe, where three-phase distribution lines are the norm, the majority of distribution lines in rural areas of the United States are single-phase, and would require upgrading to three-phase before interconnecting wind turbines larger than 20-25 kW (Princeton Economic Research 1998). Without standard agreements concerning each party’s responsibilities in paying for necessary upgrades, this weakness in the grid is a significant barrier to community wind ownership in rural areas.

Furthermore, power quality is more likely to be adversely affected by wind turbines in areas where there are fewer large electricity loads than it is in areas with higher load density (Princeton Economic Research 1998). This is yet another strike against community wind power ownership in rural areas.

\subsubsection{Cultural Barriers}

Finally, there are cultural differences between Europe and the United States (and even between continental Europe and the United Kingdom) that could be considered barriers to community wind ownership in the US. Perhaps the greatest cultural distinction involves sense of community, which is generally strong in Europe and weak in the US. From the days when the

\footnotetext{
${ }^{28}$ Schoenrich and Nadeau (1997) report that one wind developer gave an example of a project in which the equity partner earns $18 \%$ after taxes and between $0 \%$ and $3 \%$ before taxes.
} 
doctrine of "manifest destiny" drove the westward expansion, American society has become increasingly mobile, seldom standing still long enough to develop a sense of place or community. The ideal of "rugged individualism", perhaps best epitomized by the romantic image of the cowboy as an American hero, has prevailed over community involvement. The post-war rise of suburbia hastened the decline, as the symbolic front porch, with its ties to the communal street, was replaced by an unwelcoming garage, and families shifted their activities to private patios or decks behind the house, becoming all the more insulated.

Europe, on the other hand, has managed to retain a strong sense of community, perhaps enabled by a number of factors, including the small geographic size and relatively high population density of most European countries, each with a long tradition of distinct cultural identities and languages. In other words, European society is less homogenous than that of the United States, creating social and political barriers to migration and fostering stronger ties to the local community.

Cooperation on the provision of public goods is one hallmark of strong community ties.

Playgrounds, roads, parking lots, and sewage systems are often owned by the local community in Sweden, and municipally owned district heating and electric utilities - often fueled by locally grown biomass - are the norm in Denmark. In this light, community ownership of wind projects can be viewed as a natural extension of Europe's strong tradition of communities providing for their own needs. Lacking (in general) a similar community tradition, the US is likely to find the adoption of community wind ownership models challenging.

\subsubsection{Summary}

Table 8 ranks each community ownership model category in terms of each of the barriers to implementation identified above (the more solid the circle, the greater the barrier). The community-led approach appears to face the greatest number of barriers, in part because it will generally involve smaller projects than the other two categories, and any barrier-related transaction costs will be a proportionally greater expense.

Table 8. Ranking of Model Categories by Barrier

\begin{tabular}{|l|c|c|c|}
\hline & Community-led & Developer-led & Investment Fund \\
\hline Legal & $\dot{A}$ & $O$ & $\square$ \\
\hline Regulatory & $\square$ & $\dot{A}$ & 0 \\
\hline Tax & $\square$ & $\bigcirc$ & 0 \\
\hline Market & $\square$ & 0 & 0 \\
\hline Consumer/Investor & $\square$ & 0 & 0 \\
\hline Technical & $\square$ & $\bigcirc$ & 0 \\
\hline Cultural & $\square$ & $\dot{A}$ & 0 \\
\hline
\end{tabular}

The community-led approach is also somewhat penalized (perhaps unjustly) because it is most often associated with rural areas, which, as discussed above, are impacted by the bulk of the barriers identified. Rural electric cooperatives may be locked into long-term power purchase agreements that prohibit them (or their members) from generating power. Farmers have unpredictable tax liabilities (and therefore ability to profit from tax-based incentives), limited 
investment capital, and may have already sold the wind rights to their land. The rural distribution grid is often unsuitable for connecting utility-scale wind turbines, requiring either significant upgrades or a more expensive interconnection to the transmission grid. Finally, lacking a strong sense of community, many areas of the US will find it difficult to promote a community-led project.

Also disfavoring rural areas and the community-led approach are the available alternatives. Rural areas are by definition sparsely populated, and are therefore more suitable than densely populated areas for large developer-led wind projects that can benefit from economies of scale. Furthermore, farmers that allow developers to site wind turbines on their land in some cases receive $2 \%$ of the turbine's revenue with a guaranteed floor of $\$ 2000$ per turbine per year, without investing a cent (O'Bryant 2001a). This in itself is a form of participatory "ownership" with an attractive risk profile, and suggests that there may be fewer incentives in rural areas for more traditional forms of community ownership (at least among farmers that own windy land). Finally, experience in Sweden and Denmark suggests that the community-led approach, while highly successful at getting the wind industry off the ground, eventually becomes constrained by ownership restrictions, and is therefore not highly scalable. While plenty of wind capacity could be installed in the United States before ever reaching such constraints, the availability of a developer-led model that is not hobbled by such constraints, or nearly as many other barriers, suggests that the developer-led approach may be a more viable model for the US.

The investment fund approach ranks quite similar to the developer-led approach, as it must work through a developer in order to invest in projects. Generally, the most significant barrier to the investment fund approach is complying with securities laws; once that hurdle is surmounted, the "barrier profile" of the investment fund approach is more or less the same as for the developerled approach.

Thus, it appears as if the developer-led approach, perhaps in tandem with the investment fund approach, holds the most promise for community wind ownership in the United States. Both approaches can be tailored to a wide array of different project types and sizes, increasing their appeal and potential market impact.

\subsection{Potential Applications}

\subsubsection{Urban Settings}

One of the more intriguing implications to fall out of the previous discussion concerning the barriers to community-led wind projects in rural areas is the potential for developer-led community-owned wind projects in suburban or urban areas. Some of the more serious barriers facing community ownership, such as the difficulty in raising sufficient investment capital and the strength of the grid and its ability to absorb wind generation from a power quality perspective, may be mitigated in a more developed and densely-populated setting. Industrialzoned areas already exist (though may not coincide with a good wind resource), and the precedent of building power plants (fossil-fueled) within such areas has already been set. 
Equally important, the benefits of community ownership can have a large positive impact in a densely populated area. Air quality concerns are likely to be more acute in an urban or suburban setting, and a wind project would likely receive significant demonstration value as a clean technology, thereby raising awareness. Distributed generation benefits would be realized, as the power would be consumed close to where it was generated. And finally, the greatest benefit of community ownership - fostering support for wind projects by giving the community a financial stake in their success - has a good chance of countering perhaps the most serious obstacle likely to be encountered (besides finding a sufficient wind resource) - planning and permitting objections.

There are several precedents for community-owned wind projects in urban settings. As mentioned in Text Box 1, there are currently 47.8 MW of wind energy installed within Copenhagen city limits (or clearly visible $2 \mathrm{~km}$ off shore), and 27.8 MW of that is communityowned. This wind capacity provides more than $3 \%$ of the city's electricity needs, and serves as a highly visible demonstration of Denmark's commitment to wind power. Closer to home, Traverse City Light and Power, a municipal utility in Traverse City, Michigan has installed a single $600 \mathrm{~kW}$ wind turbine on a hill within site of the city, and sells the output to about 145 residential and 20 commercial customers at a premium of $1.58 \$ / \mathrm{kWh}$. Though not communityowned per se, this project is nevertheless community-supported, and has received a significant amount of attention as a "model” project within the renewable energy community (Holt 1997).

\subsubsection{Aggregate Net Metering}

Another interesting urban application employing an ownership model that has its roots in Sweden is currently unfolding in Toronto. Recall that in the traditional Swedish cooperative model, the distribution utility plays the role of a pass-through agent, channeling wind power from the cooperative's turbine to cooperative customers (who are also utility customers) and payments from those customers to the cooperative. While perhaps not common, one case study of a Swedish wind cooperative suggests that the utility simply passed the full retail rate through to the cooperative, in essence allowing the cooperative to "net meter" a jointly-owned and centrally located wind turbine (Helby 1998e). This twist on traditional net metering practices has more recently been championed on this side of the Atlantic by the Toronto Renewable Energy Cooperative, which attempted to reach a similar agreement for a wind turbine that it plans to install along Toronto’s waterfront (see Text Box 5).

While this model obviously involves utility complicity, and for that reason alone is perhaps likely to fail, it nevertheless warrants further investigation. Traditional net metering policies are most often directed at small customer-sited photovoltaic (PV) or small wind systems of less than a certain capacity (e.g., $30 \mathrm{~kW}$ ). Despite earning the full retail rate through the netting mechanism, the high costs of such systems (PV in particular) means that the economics are often poor, with payback periods of 20 years or longer. A utility-scale wind turbine, on the other hand, may produce power for around $5 \mathbb{\$} / \mathrm{kWh}$, which if net metered would be highly profitable.

Currently, three states - Connecticut, Iowa, and Ohio - have not imposed size restrictions on netmetered systems, and California has recently increased its threshold dramatically from $10 \mathrm{~kW}$ to $1 \mathrm{MW}$ in response to the power crisis. Of course, allowing utility-scale turbines to be net 
metered is a far cry from allowing a group of individuals to jointly own and net meter the facility.

\subsubsection{Selling Directly to Customers}

Another interesting possibility - that of bypassing the utility altogether - also comes from Sweden. Under the national cooperative model pioneered by Falkenberg Energi and Sveriges Vindkraftkooperativ (see Sweden case study), investors in the cooperative receive at-cost wind power (with incentives rolled in), thus ensuring that the turbine will cover its costs, and providing rate stability to the cooperative member. ${ }^{29}$ This model could potentially be replicated in deregulated states by energy service providers (ESPs), or in both regulated and deregulated states by forming a federated wind generation cooperative whose members are the many rural electric distribution cooperatives (RECs) that serve rural areas of the US. Of course, the latter would require the cooperation of the RECs in marketing the investment to their members and passing the wind generation through at cost - an uncertain proposition, at best (see market barriers section).

The prospect of ESPs, or green power marketers in particular, serving this role in restructured markets, however, bears more attention. One of the most significant criticisms of competitive green power marketing in the United States has been the low quality of product offerings, often consisting primarily of pre-existing renewable generation or perhaps even "system" power, with little new or incremental renewable generation (Rader 1998). Such criticisms have prompted some marketers to try to differentiate their products by increasing their new renewable content. Others have tried to increase participation and make their commitment to building new renewable generation more tangible by utilizing provision points to spark the construction of a new facility. ${ }^{30}$ Traveling along this continuum of increasing green power product quality, one eventually arrives at its logical end - a product containing $100 \%$ environmentally benign new renewable energy that would not have been built but for each customer's financial support. Community-owned wind projects are perhaps the ultimate example of such a product.

\footnotetext{
${ }^{29}$ The prospect of rate stability has become a valuable selling point in the face of electricity price spikes that have roiled the western United States since the summer of 2000.

${ }^{30}$ For example, Green Mountain Energy's Wind for the Future product in California promised to install one new wind turbine for every 3800 customers who signed up for the product. Even so, only 25\% of the product's energy content would come from the wind turbines; the rest would come from existing renewable energy sources.
} 


\section{Text Box 5. The Toronto Renewable Energy Cooperative}

The first whole-hearted attempt to replicate the traditional Swedish cooperative model on this side of the Atlantic is currently unfolding in Toronto, on the windy shores of Lake Ontario. The Toronto Renewable Energy Cooperative (TREC) has received planning permission to install, in cooperation with the local utility Toronto Hydro, up to three utility-scale wind turbines along Toronto's waterfront at the Ashbridge's Bay sewage treatment plant. This project is notable not only for its cooperative ownership structure, but also because it is the first utility-scale wind project to be located in a major North American metropolitan area.

From the start, TREC has been negotiating with Toronto Hydro to implement a "net billing" arrangement, in which cooperative members would receive credit on their Toronto Hydro electricity bills for their portion of the wind generation. Such an arrangement would be a precedent-setting variation of traditional net metering practices, in that the renewable generation equipment would be jointly owned and centrally located, rather than individually owned and customer-sited. As is the case with traditional net metering, TREC has argued that the net billing credit should reflect the full retail rate, including transmission and distribution charges, since the turbines will be sited within Toronto Hydro's distribution grid. Furthermore, TREC has argued that the turbines should be considered personal property, the output of which is not taxed (just like traditional net metering).

While Toronto Hydro's retail marketing arm willingly negotiated towards an agreement, several recent events have transpired to make the net billing approach unlikely. First, the regulated distribution arm of Toronto Hydro announced that it would have to spend about $\mathrm{C} \$ 600,000$ to upgrade its billing software so that it could deduct each cooperative member's share of the turbine's output from their monthly bills. Second, the Ontario Energy Board issued a ruling that would most likely require cooperative members to pay their share of transmission charges. Third, tax consultants advised that even if a net billing agreement could be reached, Revenue Canada would likely consider the project a taxable investment.

The combination of these factors have convinced TREC to revert to a traditional purchase-sale model, in which the turbine's output is sold to a third party (Toronto Hydro) and cooperative members are compensated in the form of taxable income. While this represents a significant blow to the profitability of the scheme, TREC is spinning developments positively, calling the purchase-sale model simple to understand, and highlighting the broader eligibility (and perhaps larger investments) it allows.

As of February 2001, TREC was working to finalize the purchase-sale agreement with Toronto Hydro, which will enable TREC to receive C $\$ 240,000$ in federal loans and grants that will go towards purchasing the first turbine. For more information, see www.trec.on.ca (much of the information in this text box came from TREC newsletters at this web site).

Green power marketers, moreover, are already well positioned to fill the role of aggregator and developer for such projects. In Sweden, the national cooperative model requires the cooperation of Falkenberg Energi and Sveriges Vindkraftkooperativ because Sveriges Vindkraftkooperativ (the cooperative) does not have the wherewithal to provide "balance of service" responsibility, while Falkenberg Energi (the utility) cannot offer the advantages of tax-free production that the cooperative can. In the US, however, where tax-free production is not an option, a single entity can both market and sell to customers and provide balancing services, and ESPs have been doing so in several states, some with products involving wind power.

Taking the next step to allow customer ownership of wind projects does not seem overly outlandish. In fact, some green power marketers already sell solar photovoltaic systems to their customers as an added service. While this traditional ownership structure, where PV systems are physically located on each customer's premises, is familiar and therefore perhaps easy to market, PV generation is also much less economical than utility-scale wind generation. Green power marketers could perhaps better leverage their customers' dollars and environmental impact by targeting new community wind ownership. 


\subsubsection{Developer-Led}

A German-style developer-led approach is also feasible, and a project currently in development in Minnesota - though not involving community ownership - provides a backdrop against which this idea can be examined. Northern Alternative Energy (NAE), a wind developer in the Midwest, plans to install $46660 \mathrm{~kW}$ turbines at 17 different sites in western Minnesota, for a total capacity of about $30 \mathrm{MW}$ (O’Bryant 2000). The project is divided up this way, into clusters of $2 \mathrm{MW}$ or less, in order to capture a Minnesota production incentive of $1.5 \% / \mathrm{kWh}$ for projects under 2 MW built on agricultural land. ${ }^{31}$ In combination with the federal production tax credit, which currently stands at $1.7 \mathrm{\$} / \mathrm{kWh}$, these projects will receive a combined subsidy of at least $3.2 \$ / k W h$ for 10 years. The turbines' output will be sold to Xcel Energy, formerly Northern States Power, under a 30-year power purchase agreement at an undisclosed price. ABB Energy Capital has provided \$25 million in development financing at an undisclosed rate.

This project has all the makings of a good community-owned project - small distributed wind clusters with a long-term power purchase agreement and a sizable subsidy. Furthermore, the existing financing arrangement reportedly involves 17 separate leases, contracts, and purchase agreements (i.e., one for each site), increasing the ease with which NAE could have unbundled one or more of the sites from the aggregate deal in order to initiate a community-owned project. Without knowing the structure and terms of ABB's financing of the project, it is difficult to speculate what benefits community ownership could have offered in this case, but there is a chance that NAE could have reduced its cost of capital by offering a portion of the project to community investors.

\subsubsection{Existing and New Energy Cooperatives}

While cooperatives are usually thought of as small-scale, community-led efforts - the types of community wind projects that face the largest number of barriers in the US (as shown in Table 8) - this stereotypical image can be deceptive. Cooperatives can operate at the local, regional, national, or even international level, and can be structured as centralized, federated, or mixed cooperatives. Centralized cooperatives have individuals and businesses as their members, while federated cooperatives have other cooperatives as their members, and mixed cooperatives cater to both individuals and other cooperatives (Frederick 1997). In this fashion, it is possible for even the smallest local cooperative to tap into a whole network of resources, offering its members products and services beyond its own capabilities. Thus, it might be possible, for example, for members of a small rural electric cooperative (REC) to invest - through their REC - in a federated cooperative whose sole purpose is to install and operate wind projects for RECs and their members.

While RECs were earlier identified as a potential market barrier to community wind development in rural areas such as the Midwest, there are other ways and areas in which to take advantage of the far-reaching (and often unseen) cooperative network. Several so-called "new energy cooperatives" have arisen to provide services in newly restructured electricity markets,

\footnotetext{
${ }^{31}$ The Minnesota production incentive is structured this way to specifically encourage community ownership of wind projects.
} 
most notably in the Northeast. The Connecticut Energy Cooperative and the $1^{\text {st }}$ Rochdale Cooperative NYC in New York are two new entrants to the field; while neither is offering ownership shares in community wind projects, both offer their members green power products and sustainable energy technologies such as PV systems. The Connecticut Energy Cooperative provides a particularly good example of the strong role that the cooperative network can play: during its formation, the Connecticut Energy Cooperative relied on the Cooperative Development Institute for strategic business planning, Cooperative Pioneers (a New England energy cooperative) for technical and marketing support, North Carolina EMC (a REC) for a 24hour call center, and the National Rural Utility Cooperative Finance Corporation for debt financing (Holt and Bird 2001). The existence of such a network provides advantages to cooperatives over other business structures, both in getting started and in reaching potential investors in community wind power.

\subsubsection{Green Funds}

Another potential method of financing wind energy using community investment dollars is through what the Dutch call "green funds" - bank deposit accounts that fund loans only to projects meeting specific "green" criteria. Interest on green funds is tax-free in the Netherlands, allowing banks to offer both a lower return to investors and a correspondingly lower loan rate to borrowers (usually about 1.5\% below market). While such tax advantages do not exist in the United States, there are already several banks that have set up deposit accounts to specifically fund only socially or environmentally responsible businesses or projects. Such funds typically rely on the goodwill of socially concerned investors to keep loan rates at or below market.

South Shore Bank (now ShoreBank) in Chicago has been a pioneer in this area, with its “development deposits” targeting inner-city development in Chicago's poorer neighborhoods. South Shore Bank has recently branched out into Washington state, where its affiliate ShoreBank Pacific offers EcoDeposits - FDIC-insured bank accounts that fund local businesses working towards conservation or restoration of the natural endowment of the Pacific Northwest. In the land of the spotted owl, where the rhetoric of "jobs versus the environment" is often at its most heated, EcoDeposits seek to create and sustain "jobs for the environment”. EcoDeposit rates are competitive with normal bank deposit rates, though investors can also choose to receive belowmarket rates.

A liquid, FDIC-insured savings account or certificate of deposit (CD), the funds from which would only be loaned to wind projects or renewable energy projects in general, could prove wildly popular in the United States, if not for long-term investment, at least as a place for investors to park short-term capital (i.e., as an alternative to Treasury Bills). Banks already have the infrastructure to manage such accounts, and would only need to become more familiar with the economics of wind power in order to perform proper due diligence. Wiser and Pickle (1997) estimate that reducing the debt interest rate by $4.5 \%$ (from $9.5 \%$ to $5 \%$ ) lowers the cost of wind power by $11 \%$. 


\section{CONCLUSION AND NEXT STEPS}

It will be difficult to realize the benefits of community wind ownership in the United States. Economics, not legal structure, appears to present the most significant hurdle. Large commercial wind projects - the standard form of development in the US - not only achieve greater economies of scale, but are also better able than small community projects to take advantage of the federal production tax credit and accelerated depreciation schedule, which are the primary federal incentives for wind power development. Furthermore, the relatively low population density of much of the United States, particularly in the windiest areas, generally favors large commercial projects over small, distributed, community-owned projects. Thus, from an economic perspective, community ownership is facing a tough incumbent.

Other barriers also exist, particularly in rural areas, where most of the attention paid to community wind in the United States has focused to date. Single-phase distribution lines are often too weak to interconnect more than a small $(\sim 25 \mathrm{~kW})$ wind turbine, requiring either a more distant (and costly) interconnection to the transmission grid, or else a significant (and costly) upgrade of the distribution grid. Low load densities - also often the norm in rural areas - can adversely affect power quality from wind turbines. Raising investment capital may also be difficult: farmers generally have limited investment dollars, as well as an unpredictable appetite for tax credits from year to year.

For community ownership to work in the United States, it will need to occur (A) where large commercial wind development is not possible and (B) where obstacles to community ownership are fewest. Both of these conditions are met in more densely populated areas than have been the focus of attention to date. Suburban or urban wind clusters could potentially provide a number of important benefits: distributed generation in areas that are often transmission-constrained, zero emissions in areas that often have air quality concerns, and significant demonstration value to raise awareness and educate consumers. Investment capital may be more easily raised from among a larger and potentially wealthier investor pool, and permitting - perhaps the single largest barrier to implementation - may be facilitated by giving the community a financial stake in the project's success. In short, more-so than a traditional rural project, a suburban or urban application appears to allow community ownership to play to its strengths.

Future work should investigate the potential for suburban or urban applications more thoroughly. In particular, the ability of green power marketers, which to date have not ventured into community ownership, to aggregate investors and coordinate such a project bears further exploration. Likewise, innovative approaches, such as the Toronto Renewable Energy Cooperative's attempt at aggregate net metering, should be more closely examined. After all, the pioneers of community wind ownership in Denmark and Sweden achieved success only by pushing the bounds of regulation and law, and fitting existing institutions to their needs (e.g., real estate communes). In the presence of many more barriers to community ownership than exist in Europe, successful efforts in the US will likely need to be at least as creative. 


\section{BIBLIOGRAPHY}

Alderfer, R.B., Eldridge, M., and Starrs, T. 2000. Making Connections: Case Studies of Interconnection Barriers and their Impact on Distributed Power Projects. NREL/SR-20028053. Golden, Colorado: National Renewable Energy Laboratory.

Andersen, P.D. 1998. Wind Power in Denmark: Technology, Policy, and Results. 51171/970008. Roskilde, Denmark: Danish Energy Agency.

Berger, J. 1997. Charging Ahead: The Business of Renewable Energy and What It Means for America. New York: Henry Holt and Company.

Boxer, S. and Harrop, J. 1997. The Development of Community Ownership in a Wind Energy Project at Harlock Hill, Cumbria. ETSU K/FR/0017/REP.

Centre for Sustainable Energy. 1997. Scoping Study into Community-Based Renewable Energy Projects. ETSU K/PL/00135/REP.

Danish Wind Turbine Manufacturers Association (DWTMA), www.windpower.dk

Ecotec Research and Consulting Ltd. 1999. RE Community Schemes in Europe - Relevance to the UK Market. ETSU K/BD/00194/REP.

Envall, M., president of Sveriges Vindkraftkooperativ E.F. 2001. Personal communication via email. March 2001.

European Wind Energy Association. 1997. Wind Energy in Europe - The Facts (Volume 5 Market Development). European Commission, Directorate-General for Energy.

Frederick, D.A. 1997. Co-ops 101: An Introduction to Cooperatives. Cooperative Information Report 55, U.S. Department of Agriculture, Rural Business-Cooperative Service.

Haas, R., Huber, C., Wohlgemuth, N. 2001. "Financial Incentives to Promote Renewable Energy Systems in European Electricity Markets - A Survey.” International Journal of Global Energy Issues (forthcoming)

Harrison, L. and Milborrow, D. 2000. “Commercial Reality Kept at Bay in Most of Europe.” Windpower Monthly, 16 (9), 39-42.

Helby, P. 1995. "Rationality of the Subsidy Regime for Wind Power in Sweden and Denmark." Proceedings: EWEA Special Topic Conference - The Economics of Wind Energy, September 57, 1995. Finland.

1997. “Wind Power in Denmark”, in Energy: From Fossil Fuels to Sustainable Energy

Resources, ed. Jürgen Salay (Uppsala, The Baltic University Programme, Uppsala University). 
. 1998a. Koge Wind Power Partnership. First Danish case study for the Financing Renewable Energy Systems (FIRE) project, ed. Ole Langniss, German Aerospace Center (DLR). Research funded in part by The European Commission in the framework of the Non-Nuclear Energy Programme. Joule III. Contract JOR 3-CT96-0117. September 1, 1996 to October 31, 1998.

1998b. Graabek Family Wind Turbines. Second Danish case study for the Financing Renewable Energy Systems (FIRE) project, ed. Ole Langniss, German Aerospace Center (DLR). Research funded in part by The European Commission in the framework of the Non-Nuclear Energy Programme. Joule III. Contract JOR 3-CT96-0117. September 1, 1996 to October 31, 1998.

. 1998c. Renewable Energy Projects in Denmark: An Overview of Subsidies, Taxation, Ownership, and Finance. Danish country report for the Financing Renewable Energy Systems (FIRE) project, ed. Ole Langniss, German Aerospace Center (DLR). Research funded in part by The European Commission in the framework of the Non-Nuclear Energy Programme. Joule III. Contract JOR 3-CT96-0117. September 1, 1996 to October 31, 1998.

. 1998d. Glimminge Wind Power Real-Estate Commune. First Swedish case study for the Financing Renewable Energy Systems (FIRE) project, ed. Ole Langniss, German Aerospace Center (DLR). Research funded in part by The European Commission in the framework of the Non-Nuclear Energy Programme. Joule III. Contract JOR 3-CT96-0117. September 1, 1996 to October 31, 1998.

. 1998e. Sanna. Third Swedish case study for the Financing Renewable Energy Systems (FIRE) project, ed. Ole Langniss, German Aerospace Center (DLR). Research funded in part by The European Commission in the framework of the Non-Nuclear Energy Programme. Joule III. Contract JOR 3-CT96-0117. September 1, 1996 to October 31, 1998.

. 1998f. Renewable Energy Projects in Sweden: An Overview of Subsidies, Taxation, Ownership, and Finance. Swedish country report for the Financing Renewable Energy Systems (FIRE) project, ed. Ole Langniss, German Aerospace Center (DLR). Research funded in part by The European Commission in the framework of the Non-Nuclear Energy Programme. Joule III. Contract JOR 3-CT96-0117. September 1, 1996 to October 31, 1998.

Holt, E. 1997. “Green Power for Business: Good News from Traverse City.” Research Report No. 1. Washington, D.C.: Renewable Energy Policy Project.

Holt, E. and Bird, L. 2001. Customer Aggregation: An Opportunity for Green Power? NREL/TP-620-29408. Golden, Colorado: National Renewable Energy Laboratory.

Knight, S. 2000. “Financing Bottleneck Threatens Progress.” Windpower Monthly, 16 (7), p. 22. 2001. “German Growth Goes On and On.” Windpower Monthly, 17 (3), 29-31. 
Langniss, O. (ed.), Helby, P., Joosen, S., Lorenzoni, A., Mitchell, C., Schlotterbeck, M. 1999. Financing Renewable Energy Systems (Final Report). JOULE contract JOR 3-CT96-0117. DLR: Stuttgart, Germany.

Langniss, O. 2001. Personal communication with Ole Langniss of the German Aerospace Center (DLR), March 2001.

Massy, J. 1999. “Push Towards Small Scale Development.” Windpower Monthly, 15 (3), 36-38.

Middelgrunden Wind Turbine Cooperative. 2001. www.middelgrunden.dk

Mitchell, C. 2000. “The England and Wales Non-Fossil Fuel Obligation: History and Lessons.” Annual Review of Energy and Environment. Stanford University, California, USA.

Mitchell, C. and MacKerron, G. 1994. Foreign Financing Systems. Science Policy Research Unit, University of Sussex. Falmer, East Sussex, England.

Mitchell, R. 1994. Community Involvement in Renewable Energy Projects. ETSU K/FR/00095/REP. Gloucestershire, England: Rubicon Link for the U.K. Department of Trade and Industry.

Moskowitz, D., Harrington, C., Cowart, R., Wayne, S., and Weston, F. 2000. Profits and Progress Through Distributed Resources. Gardiner, Maine: The Regulatory Assistance Project.

Network for Alternative Technology and Technology Assessment (NATTA). 1999. "UK Wind Stalled?” Renew, Issue 119, May- June 1999. On-line at http://technology.open.ac.uk/eeru/natta/rol20.html\#4

Nolo. 2001. Choosing the Best Ownership Structure for your Business. http://www.nolo.com/encyclopedia/articles/sb/which_form.html

O’Bryant, M. 2000. “Contracts Value Distributed Wind” Windpower Monthly, 16 (12), p. 21.

O’Bryant, M. 2001a. “Land Leases Helping to Save the Family Farm.” Windpower Monthly, 17 (1), 35-36.

O’Bryant, M. 2001b. “Head to Head Over Community Wind.” Windpower Monthly, 17 (2), 4548.

Odgard, O. 2000. Renewable Energy in Denmark. Danish Energy Agency for the Renewable Energy Working Group of the European Energy Network. Downloadable at http://www.agores.org/Publications/EnR/Denmark\%20REPolicy2000\%20update.pdf

Poch, D. 1999. "Notes on Regulatory Issues for Renewable Co-ops.” Presentation by David Poch to the Community Based Green Power Congress, December 4, 1999. Downloadable at http://www.trec.on.ca/advocacy.htm 
Princeton Economic Research, Inc. 1998. Distributed Wind Power Assessment. Draft report to the National Wind Coordinating Committee.

http://www.nationalwind.org/subcommittees/distributed/default.htm

Probyn, S. 2000. “New Discipline in the Grown Up World.” Windpower Monthly, 16 (9), 36-39.

Rader, N. 1998. Green Buyers Beware: A Critical Review of 'Green Electricity' Products. Washington, D.C.: Public Citizen. October.

Samstag, T. and Wizelius, T. 2000. "Wind bank opens for national business.” Windpower Monthly, 16 (6), 20-22.

Securities and Exchange Commission (SEC). 1999. Q\&A: Small Business and the SEC. http://www.sec.gov/info/smallbus/qasbsec.htm

Schoenrich, L. and Nadeau, E.G. 1997. Locally-Owned Wind Energy Feasibility Project, Final Report. Sustainable Energy for Economic Development (SEED) Project. http://www.me3.org/projects/seed/localfease.html

Swedish National Energy Administration. 2000. Electricity Market 2000. Eskilstuna, Sweden. Downloadable from www.stem.se

Swedish Wind Power Association. 2001. Current Statistics of Wind Power Plants in Sweden over 50 kW. Download from www.svensk-vindkraft.org/Kv_r_current_intro.htm

Stein, C. of the Deutsche Ausgleichsbank (DtA). 2001. Personal communication via e-mail, March 2001.

Tennis, M., Jefferis, P., and Clemmer, S. 1998. "Cooperative Wind: How Co-ops and Advocates Expanded Wind Power in Minnesota.” Research Report No. 3. Washington, D.C.: Renewable Energy Policy Project.

Tranæs, Flemming. 2001. “Danish Wind Energy Cooperatives” on Danish Wind Turbine Manufacturers Association (DWTMA) website, www.windpower.dk

Wassink, P. 2001. “Wind Turbines Sprout from Europe to US.” Associated Press via The Powermarketing Association Online, March 14, 2001.

The Wind Fund plc. 2000. Annual Report 1999. Bristol, United Kingdom.

Wiser, R., Pickle, S. 1997. Financing Investments in Renewable Energy: The Role of Policy Design and Restructuring. LBNL-39826. Berkeley, California: Lawrence Berkeley National Laboratory. 
Wiser, R., Bolinger, M., and Holt, E. 2000. “Customer Choice and Green Power Marketing: A Critical Review and Analysis of Experience to Date.” Proceedings: ACEEE 2000 Summer Study on Energy Efficiency in Buildings. Pacific Grove, California.

Wizelius, T. 1999a. Vindsamfälligheter i Sverige 1999. Downloadable from www.svenskvindkraft.org

Wizelius, T. 1999b. Vindkonsumföreningar i Sverige 1999. Downloadable from www.svenskvindkraft.org

Wizelius, T. 1999c. “Wind bank opens to Swedish co-ops.” Windpower Monthly, 15 (7), 22-23.

Wizelius, T. 2001. Personal communication via e-mail. March 2001. 